\title{
The Effect of Total Quality Management Practice on Organizational Performance: The Case of Flour Manufacturing Companies in Debre Markos Town
}

\author{
Yechale Zewdu \\ Lecturer in department of management, wachamo university, Ethiopia \\ Dereje Melaku \\ Lecturer in department of management, Debre Markos University, Ethiopia
}

\begin{abstract}
The study aims at examining the effect of Total Quality Management Practice on organizational performance in manufacturing companies (case study on Flour Manufacturing Companies in debre Markos town). The research adopted both descriptive and explanatory research designs. Accordingly, all the necessary data has been gathered from primary sources using questionnaire survey. The researcher used stratified proportional sampling technique and the number of participants was 180 employees and managers. The researcher used simple random samplings to select sample after the proportion of sample from each company have been undertaken. The researcher used descriptive and explanatory analysis with the help of SPSS version 23 . The collected data can be analyzed through descriptive statistics, (frequency, mean, and SD) Pearson correlation analysis and multiple regression for quantitative data. From the findings the major factors of TQM was lack of customer attention and low degree of implementation of TQM practice in the companies. As the correlational finding indicate that all TQM Practices dimensions to this study found to have significant and positive relation with organizational performances. As the regression finding depicted, except employee involvement other five TQM practice found to be significant with organizational performance. From the regression result customer focus and supplier quality management were the major predictors of organizational performance. This can provide a better platform of choosing the total quality management practices that lead to improved organizational performance. The researcher recommends that the Flour manufacturing Companies in Debre Markos should benchmark themselves with the best performing Companies nationally in order to find out the total quality management practices that the companies use in enhancing competitiveness. This will shed more light on the best quality management practices to adapt to increase organizational performance. Top managers on these companies recommended to give great attention to customers, because customer focus was the major predictors of performance and company existence were depends on the customers and therefore should be keen on understanding current and future customer needs and trying to satisfying then for in turn organizational performance.
\end{abstract}

Keywords: Quality, Total Quality Management Practice, Organizational Performance

DOI: $10.7176 /$ EJBM/13-17-03

Publication date:September $30^{\text {th }} 2021$

\section{CHAPTER ONE}

INTRODUCTION

\subsection{Background of the study}

In a powerful business universe of defective data and understanding, idle freedoms for execution improvement are consistently copious (Bajaj, 2018). Total quality management practice gives some better approaches for changing a bit of these new chances in to perceived chances and perceived chances into accurate improvement (Thakkar, 2006).Total quality management is considered as an organization-wide philosophy requiring employees at every level of an organization to meet/exceed customer's specifications (Addis, 2019).

As indicated by Dean and Bowen (1994), quality management has been characterized as a "theory or a way to deal with the executives" comprised of a "set of commonly strengthening standards, every one of which is upheld by a bunch of practices and methods". Quality management is the manner by which an association decides and actualizes frameworks to guarantee that quality, as in determinations are met, (Freeman-Bell \& Grover, 1994).

In today's business world, many manufacturing companies have found themselves in a great competition for survival; this has driven companies to constantly desire to improve the quality of their products and reduce costs. Many of these companies are ready to make drastic changes according to the demands of the market in order to be ahead of their competitors, but there is a constant need for maintenance and continuous improvement of quality management practices ( $\mathrm{Zu}$, Fredendall, \& Robbins, 2006). Quality difficulty is among the consuming and an undertaking issue that organizations bend over backward to succeed and make due in a serious world. As of now, the primary worry of any organization is to arrive at the greatness through excellent administrations, customer satisfaction, and cost decrease with benefit streamlining (Arauz \& Suzuki, 2004). 
According to Fassoula (2006), all manufacturing organizations try to embrace and execute a bunch of value rehearses that have been fruitful somewhere else and that will assist them with distinguishing changes in their current circumstance and to react proactively through persistent improvement in order to upgrade execution. Absolute quality administration is worried about the fulfillment of all partners through client center and embraces consistent upgrades around association's measures. This is on the grounds that; the current client is getting progressively mindful of the requirement for nature of items and administrations. Therefore, it is critical that the organizations convey their tasks with a focal point of fulfilling the client (Goetsch \&Davis 2010). Solid responsibility from the top administration is crucial in quality administration and prompting better execution (Anderson, 1995).

Today organizations are under tremendous pressure to continuously improve and upgrade themselves to the changing needs of customers to produce high quality products/services at low cost. In this pursuit, a total quality management practice is a management philosophy which assists firms to fulfill customers' demands by delivering high quality products (Kapur, 2014).

Organizational performance reveals how well an organization accomplishes its targets as far as nature of contributions, activities, development, representatives' fulfillment, clients' fulfillment, deals, productivity and total association's vision and mission. Different studies used varied organizational performance measures. Performance measures that actually demonstrate the value of an organization's management systems can be difficult to develop, use, and interpret, and different researchers have different views about performance (Feng, 2007).

In this study, the researcher measured organizational performance to prove that total quality management practice helps in stepping up efficiency in the company, leading to high performance. For the purpose of this study, performance measures defined in terms of productivity, effectiveness, better quality products, customer and employee satisfaction, in that order, these performance measures have been used in previous studies (Yusuf and Saffu, 2005). This study mainly focused on examining The Effect of Total Quality Management Practices and Organizational Performance in manufacturing companies particularly in Flour Manufacturing Companies in Debre Markos town

\section{2 . Statements of the problem}

As the researcher have mentioned at the introduction that quality related problems are inevitable more in specially developing countries. One major wrong practice made by organizations is letting the production department to take the responsibility for producing quality products believing quality is a factor of the production process only. However, many scholars believe that quality should not be the obligation of the production process only. All members of the organization should be involved to bring quality. Okland for instance, stated that traditionally, quality has been regarded as the responsibility of quality assurance and quality control departments and still it has not yet been recognized in some organizations that many quality problems originate in the commercial, service or administrative areas (Okland, 2004). Good quality management in essentially way of planning, organizing and understanding each activity and depends on each individual at each level. For an organization to be genuinely compelling each piece of it should work appropriately together towards similar objectives, perceiving that every individual and every action influence and thus influenced by others (Okland, 2004).

In recent decades total quality management become very familiar concept and many organizations are implementing quality management practice for continuous improvement. Empirical studies revealed that successful implementation of quality management practice benefited organization through improving organizational performance in many dimensions like product quality, new product introduction, customer satisfaction, market effectiveness, financial performance, operational performance (Irfan \& Kee, 2013; Psomas \& Jaca, 2016; Samat, 2006). In this regard, it is clear that quality management practice acts as a platform for any manufacturing companies to enhance their competitiveness. Regardless of this, still many organizations have been dissatisfied in the extent to which total quality management practice has been associated with constant improvements in organizational effectiveness (Das, 2006).

Total quality management is an important philosophy and gains a high degree of attention in improving organizational effectiveness. It is a set of principles that represents the basis of a continuous improvement in organization, where the organization is continuously improving in each aspect of every process, every level and every activity and could be the best objective at large (Chang \& Sun, 2007).

The implementation of quality management practice helps in gaining sustainable competitive advantage (Prajogo \& Sohal, 2004). Its guiding principles help the organizations to produce better quality products, reduces costs, increases customer and employee satisfaction and improves organizational performance (Easton \& Jarrell, 1998). It is a critical factor that helps to increase the competitiveness of an organization. Quality management is a broadly recognized management philosophy, and has become the key slogan as organizations endeavor for competitive advantage in markets (Sureshchandar, 2001).

In this regard various researches have been conducted on the effect of various quality management practices on varied performance indicators in different manufacturing companies. Masindet \& Ogollah (2014) studied the 
influence of quality management practices in cement industries without having examining the relationship of total quality management practice on organizational performance. Awino (2012) carried out a study on total quality management practice in Horticultural industry by having only focusing on three total quality management dimensions, relationship with performance, but there exist more than three total quality management practice dimensions which is best predictor for organizational performance.

Although the majority of the studies carried out state that there is a positive relationship between quality management practices and performance, as just mentioned, there is also a group of authors that did not find enough evidence to support such a relationship (Terziovski, 1997; Quazi, 2002; Conca, 2004). Quanzi \& Padibjo (1998) in their study concluded that statistically, there was no significant relationship between total quality management practices and firm performance. In additions to this, Lamport (2014) stated that, despite the great evidence about the benefits of ISO 9000, it is still debatable as to whether or not the standards improve performance and profitability.

Most of the studies conducted in Ethiopia concerning total quality management issues are largely descriptive that focused on assessing quality management practices and quality-related problems (Daniel and Fasika, 2003; Tesema, 2008; Birhanu and Daniel, 2014; Haile and Raju, 2016); and scrutinizing the relationship between TQM practices and business performance results (Alemu, 2011). These studies lack appropriate methodological and analytical rigor, and the measurement tools to examine the causal linkages between total quality management practices and organizational performance were not appropriate, since those have been used descriptive design. This, again, shows that the effect of TQM practices on organizational performance has not been addressed in the context of Ethiopian organizations at large particularly no studies found in Flour manufacturing companies in Debre Markos town. Correspondingly, Birhanu (2011) pointed out that there is lack of studies that focused on quality management practice and its consequence on manufacturing performance results such as organizational productivity and profitability in developing African nations like Ethiopia. In the significance of TQM in developing countries, Al-Qahtanietal, (2015) suggested that more studies should be carried out on the manufacturing sector to provide a better understanding of TQM implementation and associated performance outcomes. In consideration of the effect of TQM practice on organizational performance in different countries, Silaand Ebrahimpour (2005) suggests that the link between TQM and performance needs to be examined in the context of a specific county's manufacturing companies. Furthermore, Shafiq, (2017) specified that most of the studies on the relationship between TQM and organizational performance are conducted in the context of developed countries.

The studies which have been carried out in developed and developing countries, have tried to link total quality management practices and performance of firms, but findings contradict this view (Vasileios \& Odysseas, 2015; Anyango, 2012; Chow-Chua, Goh \& Wan, 2003). But those manufacturing companies including Flour manufacturing companies that have adopted total quality management practices needs to be examine the relationship between TQM with organizational performance.

From the aforementioned, particularly the researcher hardly found any previous studies which are specifically conducted to examine the effect of total quality management practices on the performance of organizations in Flour Manufacturing Company. Here, the researcher believed that there is a gap of knowledge about the relationship between total quality management practices and organizations performance in Flour Manufacturing Company, in Debre Markos town. Accordingly, this study was investigated the total quality management practices and its effect on organizational performance. Therefore, to examine the relationship between total quality management practice and organizations performance and to identify the best predictors of total quality management practice in the organization; this research was valuable.

\subsection{Research Questions}

To achieve the intended objectives, the researcher tried to address the following research questions.

1. What are the factors that affect total quality management practice for the performance of the organization in Flour Manufacturing Companies in Debre Markos town?

2. To what extent total quality management practices are implemented in Flour Manufacturing Companies in Debre Markos town?

3. What are the relationships between factors of total quality management with organizational performance in Flour Manufacturing Companies in Debre Markos town?

4. What are the effects of total quality management practices on organizational performance in Flour Manufacturing Companies in Debre Markos town?

\subsection{Objective of the study}

The general objective of the study is to assess the effect of total quality management practice on organizational performance in Flour Manufacturing companies in Debre Markos Town. 


\subsubsection{Specific objective}

The specific objectives of the study are the following:

$>$ To identify the factors that affect total quality management practice for the performance of the organization in Flour Manufacturing Companies in Debre Markos town

$>$ To analyze the extent to which total quality management practice are implemented in Flour Manufacturing Companies in Debre Markos town

$>$ To investigate the relationship between factors of total quality management practice with organizational performance in Flour Manufacturing Companies in Debre markos town

$>$ To examine the effect of total quality management practice dimensions on organizational performance in Flour Manufacturing Companies in Debre Markos town

\subsection{Scope of the Study}

The main focus of this study is to examine the effect of total quality management practice on organizational performance in Flour Manufacturing Companies in Debre Markos town. The data that the researcher used for this study was delimited to the Flour Manufacturing Companies employees and managers of each company. This study was specifically focusing on six key total quality management practices such as; top management commitment, employee involvement, customer focus, supplier quality management, continuous improvements, and education and training. The study was not considering all Flour Manufacturing Companies in the country; rather it is only delimited to Flour Manufacturing companies in Debre Markos town. The research also focused on only nonfinancial performance like employee and customer satisfaction, innovation performance, effectiveness and efficiency of the companies and production of non-defective products (quality products) of the companies. This study was not including customers and other clients of the manufacturing companies, but only included a sample of staffs from each Manufacturing Companies and managers of the Companies.

\subsection{Significance of the study}

This study provides possible suggestions for the manufacturing Companies with regard to quality management practice that is serving as a source document to the organization. In addition, it helps the researcher to acquire knowledge, skills, and practical experience about total quality management practices and finally getting award of masters of business administration. Furthermore, it will help as a source document and as a stepping stone for those researchers who want to make further study on the area afterwards. All in all, the findings of this study also will assist the government and Manufacturing Companies regulator when they are crafting total quality management policies so that quality managers and management representatives operate from an informed position with regard to total quality matters and when drawing quality improvement plans.

\subsection{Limitation of the study}

The study examined the effect of total quality management practice on organizational performance, in a case of Flour manufacturing companies in Debre Markos town. Due to financial and time constraints, the scope of the study was limited to Flour Manufacturing Companies available in Debre Markos town which, in a broader sense, may limit its generalization to the all over country's Flour manufacturing companies. The data's which were collected doesn't give the holistic overview of effect of total quality management practice on Flour manufacturing companies in Debre Markos town. Holistic overview of data means, know that each change you make to one part affects the whole. But the respondents sometimes looking at a single way of problem or solution and unwilling to think about it differently, irrelevant information, and high non-response rate makes the study not give a holistic overview. The study was only focused on six quality management practice variables; it was missing to address all total quality management practice variables that have impact on the dependent variable of organizational performance. The study also only considered the staff workers and managers who spent all the working day in the companies by excluding customers and other clients were the major limitations of the study.

\subsection{Operational Definitions Of key Terms}

Terms: Quality, Quality management, Total quality management, and Organizational Performance

$>$ Quality: It is the state of conformity of the previously set requirements within the product/service. The new definition of quality meant the organization meeting various customers' objectives.

> Quality management: Is a managerial approach geared towards in cooperating inherent managerial tendencies of planning, control and improvement of quality in the organization.

$>$ Total Quality Management (TQM): Is strategies that implemented by organizations' that focus on handling the total organization as a whole to provide products and services that fulfill customers' needs.

$>$ Organizational performance: is the indication of attainment of organizational goals and objectives. 


\subsection{Organizaiton of the study}

This study organized in to five chapters. The first chapter was the introduction part that includes background of the study, statement of the problem, research question, Objective of the study, significance of the study, scope of the study, limitation of the study, operational definitions and Organization of the paper. Chapter two focused on related literature on theoretical and empirical reviews of total quality management practices and organizational performance. The researcher also was developing conceptual framework and research hypothesis. Chapter three was about the research methodology that provides research design and approach, sample design, population, sample size and sampling instrument and data collection techniques, methods of data analysis and interpretation. Analysis of demographic profile of respondents, hypothesis testing and analysis was presented in chapter four. The paper was ends with discussions, conclusion and suggestion for future studies in chapter five.

\section{CHAPTER TWO}

\section{REVIEW OF RELATED LITERATURE}

\subsection{Introduction}

This section introduced the theoretical and empirical reviews related to the study. A theoretical part focused on the adoption of theories and concepts that were presented by distinguished authors in relation to total quality management practices implementation and organizational performance. The study guided by the five theories; Deming's theory, Theory of constraint and Resource Based Theories (RBT), Crosby's Approach and Kanter's Structural Empowerment Theory. The underlying assumption for choosing the most appropriate theoretical framework in this study is governed by a holistic approach that captures the main elements of total quality management practice.

\subsection{The concept of quality Management (QM)}

Definition of quality exists regardless of product while at the same time, regardless of manufacturing or service industry. Defining quality can be a cumbersome affair considering that quality appeal is unique to individuals. The role of the people defining quality also plays a major role in its definition. Clients or customers might have a difficult time defining quality but when they see it, they can tell what it is (Gitlow, 2000).

Total quality management is a managerial approach geared towards in cooperating inherent managerial tendencies of planning, control and improvement. It depends on the accompanying standards: quality integration, quality first, consumer loyalty, constant change, continuous improvement, factual-based decision and workforce involvement (Gitlow, 2000).

From the initial focus of quality management being the checking of the final product against standards, the quest has been to eliminate product failure. In the recent past, quality management thinking has moved up from the work place to other disciplines, it became apparent that every function of a business contributes to outcome thus needs to be subjected to some quality standard (Gitlow, 2000). Additionally, the terminology of quality management from the time it was known as inspection evolved to quality control, which evolved to quality assurance. As if not complete in maturity and evolution still continues up to date (Hoyle, 2007).

\subsection{Theoretical Literature Review}

\subsubsection{Deming Theory}

In the field of quality several quality expert's, such as W. Edwards Deming, Philip B. Crosby, and Joseph M. Juran, has made significant contributions. To this study the Deming's theory on quality is important because it gives insights on how organizations should work in order to continuously improve quality that ultimately may improve the performance of organizations. Deming (1986) proposed that an organization's commitment to quality signaled its intent to stay in business. According to Deming's theory quality of goods and services can be improved through enhancing the internal environment ensuring continuous improvements and checking the results on statistical balances.

According to also Deming (1986) no quality management system could succeed without top management commitment; it is the management that invests in the processes, creates corporate culture and also selects suppliers and develops long-term relationships. Deming noted that organizations should seek to correct the variations from their quality norms before the system deteriorates. The theoretical approach of Deming (1986) in respect to the quality management system detailed by Hubert (2005), and it pictures the creation of an organizational system that adopts cooperation and learning to facilitate the implementation of process management practices. This, in turn, leads to the continual improvement of the processes, products, and services and helps to introduce employee satisfaction. These are critical to promoting customer focus, and, ultimately, helping in the survival of any organization.

Organizations are comprised of the office which forms systems. Throughout the years Deming dense his rationality into 14 focuses which progressed toward becoming activity things for top administration to embrace. As indicated by Dale (2003), Deming kept up that his 14 points can be connected anyplace, to little organizations 
and substantial ones, to benefit industry and also to manufacturing. He likewise focused on that it is an arrangement of work that decides how function is performed and it is just chiefs that can make the framework.

The responsibilities of top management should take the lead in changing processes and systems (Oakland, 2004). Leadership plays a crucial role in ensuring the success of quality management because it is the top management's responsibility to create and communicate the vision to move the firm toward performance improvement. Top management is responsible for most quality problems; according to Kamanda (2010) it should give employees clear directions on what is considered acceptable work, and provide the methods to achieve it. These methods include an appropriate working environment and climate for work that is free of fault finding, blame or fear and instead provide clarity of issues, communicate effectively and provide appropriate environment for work to enhance performance (Lamport, 2014). Deming's quality improvement theory is relevant to this study in that quality management practices is a quality management system which can be used to enhance quality of products and services through continuous improvement and which organizations can use to realize performance. Deming administration strategy is about the formation of a hierarchical framework that realizes participation and learning for encouraging the usage of process administration hones, which, thus, prompts constant change of procedures, items, benefits and to worker satisfaction, both of which are basic to consumer loyalty, and at last, to the authoritative survival. This research planned to discover the effect of quality management practices and organizational performance in Flour Manufacturing Company. Along these lines to know the connection between employees' procedures and the organization systems the study should be educated by Deming's theory, in this manner, this theory is significant to this study.

\subsubsection{Theory of Constraints (TOC)}

These days, organizations battle to get by in a worldwide contest. Each organization attempts to track down the best way of thinking which is reasonable with their system to acquire any and each benefit among their adversaries. Organizations ought to be more centered around understanding their own design as far as cycles whether they are in the creation or administration area. The Theory of Constraints is frameworks based administration reasoning that is utilized to aid the persistent improvement of a framework's exhibition by zeroing in on center issues that are keeping the framework from accomplishing its objective (Inman, 2009)

Initially TOC is utilized to design the creation cycle and distribute assets yet its substance is further developed step by step as the innovation advances and contest between rival organizations expansions in business world. It isn't of significance which area your organization has a place on the grounds that TOC is really founded on framework improvement. It depends on the possibility that each framework has no less than one bottleneck which can be characterized as any sort of circumstance that hinders the framework to arrive at superior level as far as its motivations (Goldratt, 1990).

According to Gupta (2002), the concept of TOC that every system must have at least one constraint and the existence of constraints represents opportunities for improvement. The one principle part of TOC, which contrasts from conventional improvement draws near, is the manner in which it assesses improvement endeavors. Numerous quality improvement endeavors are centered on accomplishing the greatest expense decreases.

Theory of constraints, rather than the conventional consistent improvement methods, depends on the reason that the presentation of a framework is restricted by the most minimal performing part or interaction in the framework. Henceforth, to work on the general execution of a framework, Theory of Constraints specifies that any improvement exertion should be aimed at expanding the exhibition of the requirement (Goldratt, 1990). It is contended (Dalton, 2009) that working on the exhibition of a non-imperative is a squandered exertion in light of the fact that the limitation will in any case be deciding the general execution of the framework.

According to Humair and Williams (2006), the existence of constraints may lead to low quality of produce if not checked. The theory of constraints explains how strategies should be implemented in order to improve the performance of organizations through superior quality of products and services. The theory of constraints is therefore very informative with respect to this study in that it explains on the ways that can be taken by entities to ensure continuous improvements. An effective management will realize the means of ensuring quality of products is improved over time (Shahin and Dabestani, 2011).

\subsubsection{Resource-Based Theory (RBT)}

The resource based view (RBT) theory has widely been used in the studies of organizational performance (Innocent, 2015). The RBT talks about the organizational unique resources and capabilities which differentiates the one organization with the other organizations in the similar industry. The RBT also tries to answer the question that how can organizations achieve the competitive advantage over other industry organizations and enhance their organizational performance?

The resource-based view of the firm and the resultant resource based theory provide an important structure for construing and forecasting the underpinning of a firm's competitive advantage and performance (Palmatier, 2014).It is thus important for firms to identify their core competencies, capitalize on them in order to improve their results. It is the rare resources that provide a company with chances of improving performance particularly when they cannot be copied by competitors in the market. 
Hsu and Pereira (2008) stated that RBT helps the organization in identifying its unique internal resources which not only enhance the organizational performance, but also creates the competitive advantage for an organization. The RBT suggested that organizational achievements are truly based on the internal properties of an organization. Both organizational assets (tangible and intangible) and capabilities (internal knowledge and competencies) are defined as the organizational internal properties (Chuang \& Lin, 2017).

Similarly, the RBT considered that an organization contains the different types of organizational resources such as, assets resources, capabilities resources, process resources, management competencies, technological resources and knowledge resources (Barney, 1991). These resources and capabilities enhanced the organizational performance and works as a basis of competitive advantage. This theory puts it that it is more economical and feasible to control a firm's internal environments as opposed to the external environments. To this end, organizations should strive to improve their processes to ensure improved quality of products. Consequently, therefore, companies should focus on improving the internal processes in order to enhance their performance.

According to Barney (2001), a firm develops competitive advantage by not only acquiring but also developing, combining, and effectively deploying its physical, human, and organizational resources in ways that add unique value and are difficult for competitors to imitate. The theory categorizes resources in terms of valuable resources and rare resources depending on their availability. Accordingly therefore, a valuable resource creates value to customers and leads to the organization having competitive advantage, where rare resources can be acquired by a few companies. In the circumstance that the organizations need to attain a sustained competitive advantage, then it has to differentiate its products and ensure the system runs efficiently. Barney (2007) suggests that to transform a short run competitive advantage into a sustained competitive advantage requires that these resources be heterogeneous in nature and not perfectly mobile. This in effect results to valuable resources that are neither perfectly imitable nor sustainable without great effort (Hockman \& Grenville, 2004).

In the RBT, a distinction has emerged between resources and capabilities (Makadok, 2001). A resource is an observable (but not necessarily tangible) asset that can be valued and traded as a brand or a patent. A capability, on the other hand, is not observable and is hence intangible and hard to value (Karthi, 2012). Two key features distinguish a capability from a resource: a capability is firm-specific since it is imbedded in the organization and its processes; and the primary purpose of a capability is to enhance the productivity of the other resources that the firm possesses (Makadok, 2001).

TQM practices like top management commitment and support, building strong relations with customers and empowering employees through training and improving reward systems coupled with other organizational resources are all valuable resources that can enhance organizational performance in terms of employee and customer satisfaction. Thus organizational preparedness determines what kind of quality management systems to pursue, since the resources that an organization has will influence what the firm does or does not do. The strategies so undertaken will then influence the performance of the firm and help the firm gain a competitive advantage in the market place, resulting to enhanced performance. Therefore, this theory supports variables of the study: continuous improvement, customer focus, and the commitment of the top management.

\subsection{Empirical Literature Review}

\subsubsection{Organizational Performance}

Performance reflects the behavior measured by the individual's ability to contribute to the achievement of the objectives of the organization (Qureshi, 2011).Performance is the indication of attainment of organizational objectives. Organizational performance is defined as the output of the firm's operations or achievements of firm's goals. As noted by Vassilakis and Besseris (2009) organizational performance indicates the attainment of the firm's organizational objectives.

Ramamoorthy (2007) defines organizational performance as the output of the organizations' achievement or operations in three dimensions: organizational, financial effectiveness, and operational effectiveness. Nonfinancial and operational performance includes market share, product quality, the introduction of the new product, and market effectiveness. Organizational performance is a multinational variable or construct that can be measured using various indicators including product quality effectiveness, customer satisfaction, and financial performance. Whereas operational or non-financial performance includes, market share, market effectiveness and new product introduction; financial performance includes the profitability and sales growth; and organizational effectiveness is an extent to which organizations achieve their effectiveness.

Continuous performance is the focus of any organization because only through performance organizations are able to grow and progress. The performance of firms is influenced by a number of factors which may be within the firm or outside the firm. According to (Hitt, Hoskisson \& Ireland, 2013), manufacturing firms have an overall strategic goal of maintain a performance that leads to a competitive edge in the market. These factors that determine the performance of firms may be termed as constraints (Hakala, 2011). Psomas and Kafetzopoulos (2012) argue that performance contributes to providing the competitive advantage to the firms in high competition in the market. The company takes advantage over its competitors and performs better in business. Beside this, the current study 
focused on non-financial measures of performance and it was carried out in a flour manufacturing company, Debre Markos town.

Prajogo and Sohal (2003) in their study noted the relationship between TQM practices and product quality performance in Australia, encompassing both manufacturing and nonmanufacturing sectors. The findings suggested that TQM was positive and significantly related to product quality. The study used reliability, quality performance, durability and conformance to specifications to measure performance. Other performance measures were recommended.

According to Arend \& Levesque (2010), when a firm responds to customer needs efficiently, it has a chance of establishing a competitive edge over other firms in the market and this improves its performance. Thus, it is crucial for firm to critically consider its competitiveness in order to enhance performance. Barney \& Hesterly (2010) idealize that a firm should seek to possess those resources that competitors cannot have as this puts them in a competitive position. There are other factors that affect performance, for instance, managerial experience, financial resources, quality management, brand names, internal processes and the political environment.

According to Crosby (2009) TQM philosophy and methods can lead to improvement in business and operational performance, such as: improved process yields, motivated employees, satisfied customers, improved quality, productivity and profitability. The scope of performance outcomes, based on quality initiatives, therefore, appears to be very broad.

One of the main elements to achieve an effective organizational management processes is the performance measurement. The performance of one organization can be directly related to its ability to achieve their strategic and financial objectives (Lin, 2006). The performance of organizations was largely neglected in past research, whereas some other (Katou, 2008) who were discussing the organizational performance with reference to the financial performance only. Stock (2000) were also discussing the organizational performance through measuring both financial and market harmonic performance which includes the return on investment measures (ROI), sales profit and growth and market share progress. However, the current study focused on non-financial performance such as; employee and customer satisfaction, innovation performance, effectiveness and efficiency of the companies and production of non-defective products (quality products) were taken as performance measurement variables measurement in Flour Manufacturing Company in Debre Markos town.

\subsection{Quality Management Practice in the Organization and its relationships}

Total quality management practice involves the application of quality management practices in all aspects of organization. An extensive literature survey has been carried out to select TQM frameworks for this study. Research into total quality management has identified many critical success factors that affect an organization's position. Oakland (2000) noted defined TQM as a process of addressing clients' needs and is guided by the tenets of being reliable, available and most important being cost effective. When applying TQM in an organization, the following are the pre-requisites: In line with this, the researcher has prioritized and selected the following for Flour Manufacturing Companies in Debre Markos town.

\subsubsection{Top Management Commitment and organizational Performance}

According to Hackman and Wagenman (1995), quality is ultimately viewed as the responsibility of top management. This is because creating the systems that produce goods and services in any organization is the core responsibility of the top management, so any successful implementation of quality management strategies depends on the commitment of the top management to the quality management strategies. Moreover, according to Pheny and Teo (2003), top management should communicate the quality management strategies to the entire organization so as to create awareness, interest, and desire to follow through with the necessary action. They ought to likewise give the vision of where the organization needs to go with its quality endeavors and supplant the current culture in the organization with one that upholds quality administration techniques (Samat, Ramayah,(2006) \& Yusoff, 2008; Mohante \& Lakhal, 2006).

Top management commitment is among the outstanding factors critical to the success of TQM implementation in any organization. Top management has immense influence on the attitude and strategic direction of the organization. For an organization to reap the benefits of successful TQM implementation the top management must allow and encourage employees throughout the organization to conduct necessary actions on their own initiatives and be actively involved in organizational improvements. Top management must provide necessary resources to promote new ideas and improvement opportunities. The International Organization for Standardization (ISO, 2001) considers top management as an individual or group of individuals who executes the managerial functions of planning, organizing, directing and controlling in an organization at the uppermost echelon. The primary intent is to establish an environment where employees are comprehensively involved and whereby they can work effectively and make recommendations to achieve the objectives of the organization. Management should commit to their leadership and actively take part in the formulation and implementation of strategy. Commitment of top managers involves engaging in and maintaining behaviors that help others achieve a goal (Cooper and Edgett, 2005). 
There is a need for firms to involve all employees in planning productivity objectives because it motivates them to achieve them (Besterfield, Michna and Sacre, 2001). Total quality management involves processes changes and this calls for involvement of all stakeholders. It is for this reason, that the top management should be committed to quality and should keep a budget for quality improvements. It is crucial to note that the firm's top management is responsible for making sure that the quality of goods and services are within the threshold expected by customers. In pursuit of quality goals the top management should encourage and reward the achievement of quality goals to staffs (Mann, 2009).

According to Bass (1990) the study on participative decision-making is most likely to be acknowledged by those influenced by it, adding that everybody in the organization, top to bottom, should be a team and part take in quality issues. Individuals are the originators of concepts and invention and their skills, knowledge, expertise and cooperation should be combined and ideas related to higher fulfillment implemented for higher quality decisions. Deming (1986) argued that a major proportion of quality problems can be solved by management, hence the need to have good leadership that is committed to the quality program. For a quality management strategy to bring around performance, the review of the process through system audits must become an integral part of implementing any quality management system.

Javed (2015) conducted a study whose objective was to empirically investigate the effect of top management commitment on the success of total quality management. The Correlation analysis explained a positive moderate relationship between top management commitment and success of quality management. That is, top management commitment is positively related to the success of quality management in an organization. Wahid and Corner's (2009) study on service firms in Malaysia established that ISO implementation is a critical factor on performance. Analysis of qualitative data using thematic analysis was able to identify several critical factors of ISO 9001 implementation. The study ranked the support and involvement of the top managements a most critical factor. The conclusion made from the results stated that the success and sustainability of ISO 9000 is influenced by top management.

Chin and Choi (2003) study focused on the impact of ISO and the firm's performance established that the most important factor was the way the certification is perceived by top management, as this is classified as the most influential factor for implementing the standard. If certification is perceived positively, top management will provide full support to it. After all, the top management acts as a driver in the implementation of quality management systems through the provision of the necessary resources, which are major factors in continuous improvement through the creation of values, goals and systems to satisfy customer expectations and improve the organization's performance. The study concluded that although top management commitment plays a vital role on quality performance, other studies should be done to establish whether ISO certification is internally or externally motivated. However, the study did not address other factors like continuous improvement and customer focus which are the current study taken into account.

According to Ahuja (2009), top management can influence achievement of manufacturing performance advancements by putting in place structures for QM implementation, setting up just reward and recognition structure in the organization and ensuring that resources for managing change in the organization are availed on time. It takes necessary planning and a focused QM implementation plan, adequately aided by top management through engaging in organizational cultural improvement over a considerable period of time to appreciate the true results from the comprehensive TQM implementation program. From this understanding Top management may support the development of quality management systems. They ensure an organization has an enabling atmosphere for employees to work towards achieving certain business objectives. Bhat and Rajashekhar (2009) believe that the support of the top management helps to improve the performance of the organization.

\subsubsection{Employee Involvement and organizational performance}

Total quality management (TQM) defined as working environment in which worker obtains the ability, trust and commitment to improve productivity, meet the needs and desires of the clients, to achieve objectives and values of organization (Obeidat, 2018 and Besterfield, 2014). TQM practices require decisions to delegate to average and operational level, the process of delegating and involving staff to make decisions about their tasks is a good motivational method, as well as sensitizing them to decisions they make (Juda, 2014).

Employee involvement is viewed as a way to allow employee participation, the commitment on the part of the management to allow employees participate in decision-making and reflect a change in culture. Employee involvement is seen as a way to empower employees to take part in solving problems and making decisions in an organization (Eng and Yusof, 2003). According to Kahreh, (2014) employee involvement motivates employees to work towards achieving the organizational objectives. It makes employees to feel that they form an important part of the organization. Harrington, (2012) claim that empowered and trained employees is likely to recognize the achievement of that organization. Employees are view their organization and jobs from a different perspective. Some management leaders and theorists posit that employees need to exercise imagination and that this can only be achieved by involving them in the organization. According to Green (2012), the object of employee empowerment is to encourage constructive thoughts and creative thinking among employees. 
Creativity enables employees to have the ability to apply administrative and technical innovative ideas to explore opportunities to meet customer needs and to meet total quality standards (Al-Zoubi, 2012). Employees can become creative at work when the organization gives them freedom to participate in its activities and decisionmaking. The idea is that all members of the organization should be conscious of quality since quality can only be made by people. An organization needs to achieve involvement, participation of its employee, and top management commitment by embracing values that translate into good and concrete practices (Al-Zoubi, 2012).

Making the team members involved in implementing TQM has become increasingly important in organization (Zadry \& Yusof, 2007). Managers do not really understand what employee empowerment means and fail to establish boundaries for employee empowerment. Employee empowerment is a philosophy or strategy that enables people to make decisions about their job. Workers feel empowered when they are in an environment where their ideas are respected and they feel free to make suggestions without fear of ridicule by superiors or fellow workers (Gaudreau and Meyerson, 2012).

Total quality management practices are responsibility of all employees in organization. Therefore, they strive to promote collective work, encourage, achieve continuous improvement, and build a greater contribution to solve, productive and operational problems among different employees. The participation of staff in efficiency of organization will increase its production by motivating employees to participate in setting objectives and making greater use of this participation in meeting the challenges of market (Titi, 2010). Ahire and Dreyfus (2000) added that people responsible for employee performance are those who are keen to participate and contribute to continuous improvement as participation of employees leads to a frank discussion of problems, issues and responsibilities with people within organization to resolve them, and their understanding of importance of their contribution and their role in innovation and creativity in promoting the objectives of organization.

\subsubsection{Customer Focus and Organizational Performance}

The pith of this idea is to fulfill customers with the necessary work appropriately from the first run through, just as to think about all representatives to clients' focal point of action and consideration, whatever the idea of their capacities and representatives should research responses to customers on the administrations or items gave (Sugannthi \& Samuel, 2015). As the intended client is individual in which all activities and efforts are focused, in order to achieve or exceed his/her needs and expectations. Thus, customers current, future needs and desires must be determined (Boukmeish, 2010). It also includes dimensions of customer focus, identifying internal and external customers, knowing customer needs, desires, studying customer's trends, expectations, following up the complaints and taking the views when developing a product or service, and gaining new customers (Sugannthi \& Samuel, 2015). Therefore, organizations should identify their customers, identify their needs and desires by following some means that enable organizations to reach this through personal interviews, questionnaires, establishing a system of suggestions, and ensuring participation by customer in quality teams (Juda, 2014).

Proper implementation of quality management practice dimensions attains higher level of organizational performance. Customer focus is one of the major indicators of performance enhancement. Some scholars find that total quality management implementation increases customer satisfaction and improve organizational performance (Lee 2010; Liu, 2002). In total quality management practice, changing needs of the clients are identified and performance of the organization is measured against customers' requirements (Bullington, 2002; Deming, 1986; Hackman and Wageman, 1995). Asikhia (2010) find that customer orientation is positively associated with firm performance. Based on the above empirical literature, the researcher expected that customer focus is one of the major dimensions of total quality management and it is a key predictor of organizational performance. Here on this literature, organizations that have adopted total quality management view the customer highly and always strive to meet and exceed their expectations. In a total quality practice, every member of the organization aims at satisfying the customer through listening to their concerns, ensuring that their concerns are addressed in the best way possible and always remaining in touch with them. It is paramount for the members of the organization to appreciate the customer because the success, competitiveness and survival of the organization are closely intertwined with customer satisfaction. Results of these studies suggest that customer focus, one of the key dimensions of TQM, may be a key predictor of the firm's performance. The empirical research on customer focus and organizational performance particularly in Flour Manufacturing Companies of Debre Markos was further elaborating this relation. Accordingly the researcher proposes the hypotheses of the study based on it.

\subsubsection{Supplier quality management and organizational performance}

Inputs from suppliers constitute the first phase of producing the products and/or services in a firm. High quality inputs provide high quality products and/or services. Therefore, the suppliers should adopt TQM and be involved in this process. Effective supply management practices enable the suppliers to adopt quality management and deliver reliable and high quality products and/or services timely.

Ellram (1991) as refered to in Kaynak (2003) attested that the essential administration of provider connections is exceptionally fundamental for the accomplishment of associations due to the degree of responsibility it requires and the nature cutthroat data being traded among the entertainers. Supplier quality management enables firms to select few and a highly reliable supplier purely on quality considerations, which in turn secures the provision of 
high-quality items (supplies). Corresponding to the above TQM practices, several empirical studies recognized the significant and positive relationships that supplier quality management has with organizational performance (Kaynak, 2003; Kannan and Tan, 2005; Sadikoglu and Zehir, 2010; Baird, 2011; Phan, 2011; Sweis and Saleh, 2017; Chauke, 2019).

Previous studies have found that supplier quality management positively affects organizational performance (Ahire 1998, Phan, 2011, Kannan, 2005), inventory management performance, innovation performance (Phan, 2011, Kim, 2012), and overall firm performance(Powell, 1995, Zehir, 2012).From the literature reviewed it can be postulated that keeping close relationships with suppliers would result in improved organizational performance. From here, the researcher was proposed hypothesis to be tested.

\subsubsection{Continuous Improvement and Organizational Performance}

Continuous improvement is defined as a philosophy to ensure the success and progress of organizations, which are based on attracting and retaining customers, providing all their requirements and needs, developing performance processes, as continuous improvement achieves profitability and competitive advantage and achieves objectives for successive success (Jonsdottir, 2014).

Continuous commitment on the implementation of quality management does have a significant positive effect on firm performance. Continuous improvement endorsed by organizations stimulates organizational members for innovations and quality performance (Prajogo and Sohal, 2003). Kiprotich (2018) argued that continuous improvement significantly affects every indicator of the company's operational performance and thereby increase organizational competitiveness. Similarly, Kemboi (2016) indicated that continuous improvement was the only practice that brings about and sustains organizational productivity, which in turn is one of the indicators of operational performance according to Salaheldin (2009). Other studies also found a direct and positive effect of continuous improvement on operational performance (Agus, 2005; Arnold, 2014; Olepein, 2015; Salah, 2018). From the above discussion it is observed that the literature supports the relationship between continuous improvement and organizational performance. Clearly, there is evidence to suggest that there may be a relationship between organizational performance and continuous improvement.

\subsubsection{Education and Training and Organizational Performance}

According to Nair and Prajogo (2009) training all employees concerning total quality concepts and quality management $(\mathrm{QM})$ requirements is vital for the success of the organization. The employee owns it because they have been empowered. The training also acts as a motivation to the employees. Training involves informationgiving and a dry run of skills. Training concentrates on organizational stability than it is with change. Training can bolster the employee's inventory of skills, it can prepare employees for future growth, it prepares employees to do the job more efficiently and effectively, and it prepares employees to make positive contributions to the general working milieu (Kim, 2009).

Efficacious training imparts in employees crucial knowledge about the industry and the structure of the organization and it also improves employees' devotion to the organization, motivation, and work performance. Training of employees on how to produce reliable and high quality products and/or services harnesses their full participation in the production stage and is more fruitful leading to an increase in customer satisfaction and customer complaints reduction (Sadikoglu \& Olcay, 2014).

Bunney and Dale (1997) suggested that for training to be effective it should be executed in a situation that employees can rehearse what they have been taught. Particular training needs should be put into consideration for teams involved in the improvement of quality. Local role models should be availed so that employees can network with and consult from them during and after training. A programmed approach on the utilization of techniques and tools should be employed. Managers understanding should be encouraged and clear policies be put in place that a single technique or tool cannot be a solution to all issues. Facilitators' responsibility during training should be to encourage the use of techniques and tools in daily work processes. The key virtues to be observed during training are patience and persistence because different people absorb new knowledge, attitudes and skills at different rates. Over and above, employees should be encouraged to take an active role in measuring and analyzing performance of the organization's processes they engage in.

Helper and Kiehl (2004) found that efforts to promote employee involvement led to higher wages meant to offset the additional energy spent in achieving the essential advanced skill levels. Employees of organizations that adopt total quality management (TQM) are often expected to carry out optional duties such as documenting new procedures and giving quality improvement ideas. TQM embracing organizations must promote and utilize quality-related training to ensure that employees properly implement new procedures and acquire the skills needed to conduct internal audits and continuously improve other procedures. Clearly, there is evidence to suggest that there may be a relationship between organizational performance and education and training.

\subsection{Conceptual Framework of the study}

A theoretical frame work is a conceptual model of how one makes logical sense of the relationship among the several factors that have been identified as important to the problem (Sekeran, 2003).Considering the various 
dimensions of total quality management practices and measurement of organizational performance and that will propose and adopt a research framework that will encompass the following five dimensions of quality management practices: Top Management Commitment, Customer Focus, and Employee involvement, supplier quality management, Continuous Improvements, and Education and Training.

For organizational performance measurement non-financial performance measurements such as: employee and customer satisfaction, innovation performance, effectiveness and efficiency of the companies and production of non-defective products (quality products) that companies were used to cover non-financial aspects of companies' performance. The Model is based on the premise that: Excellent expected results with respect to Performance are achieved through effective measurement of total quality implementation practice. The organization performance model is depicted below in Figure 2.1.

Figure 2.1. Conceptual Framework diagram

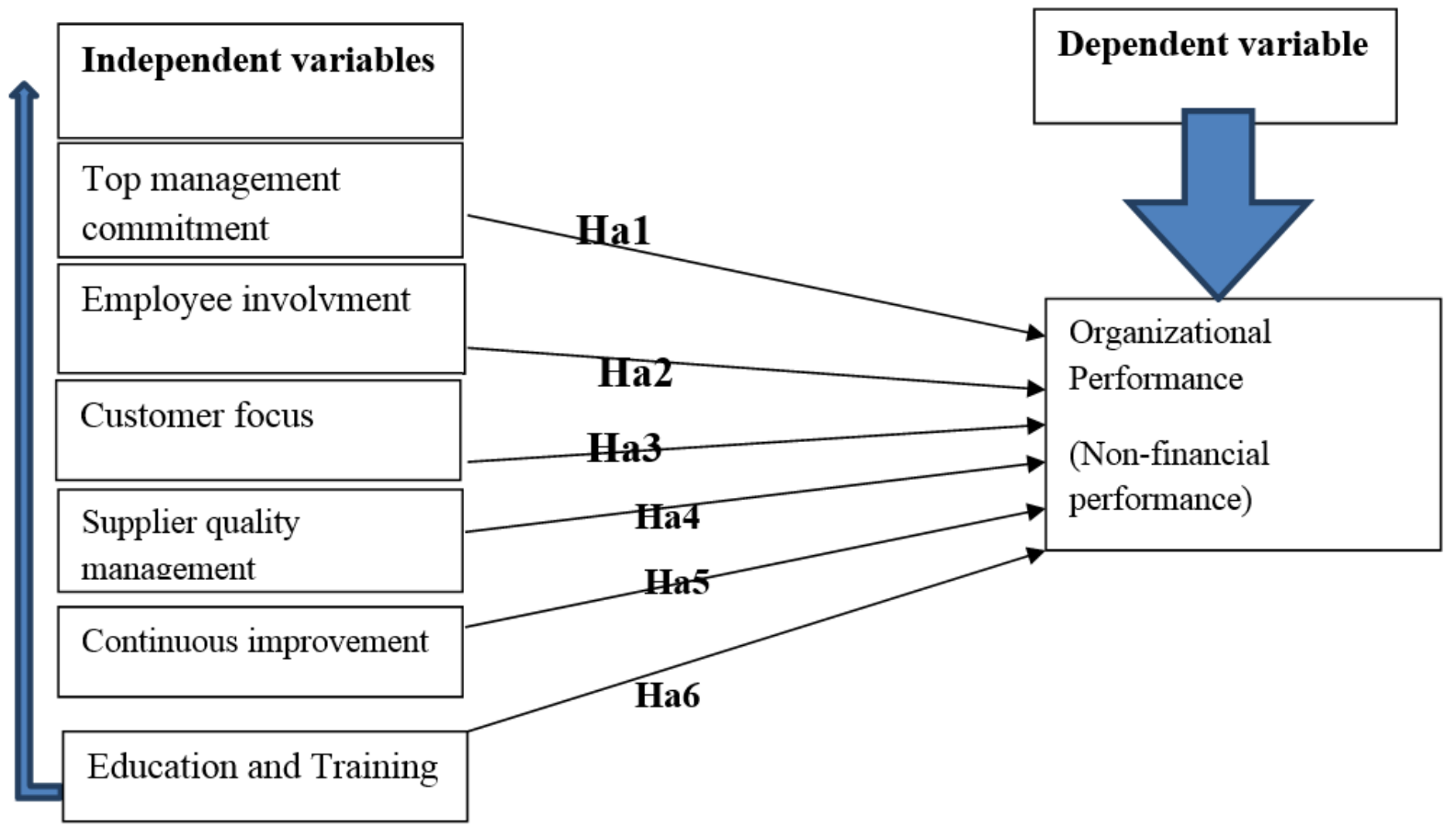

Source: adopted from the literature and modified by the researcher

\subsection{Research hypothesis}

Based on an intensive review of extant empirical literature, and conceptual framework of the study, the researcher developed the following hypotheses to indicate the relationship between each TQM practice and its effect on organizational performance.

$>$ Ha1: There is a significant, positive relationship between top management commitment and organizational performance in Flour Manufacturing company in Debre Markos town.

$>$ Ha2: There is a significant, and positive relashipship between employee involvement and organizational performancein Flour Manufacturing company in Debre Markos town.

$>$ Ha3: There is a significant, and positive relationship between customer cocus and organizational performance in Flour Manufacturing Company in Debre Markos town.

> Ha4: There is a significant, and positive relationship between supplier quality management and organizational performance in Flour Manufacturing Company in Debre Markos town.

$>$ Ha5: There is a significant, positive relationship between continuous improvement and organizational performance in Flour Manufacturing Company in Debre Markos town.

$>$ Ha6: There is a significant and positive relationship between education and training with improving organizational performance in Flour Manufacturing Company.

\section{CHAPTER THREE}

\section{RESEARCH METHODOLOGY}

\subsection{Research Design and Approach}

\subsection{Research design}

Research design is a set of advance decisions that make up the master plan specifying the methods and procedures for collecting and analyzing of data (Burns \& Bush, 2006). There are different research designs available for 
conducting research. These are exploratory, descriptive and explanatory research designs (Yin, 2009). For the purpose of answering the research problem, the researcher used both descriptive and explanatory research designs. According to Kothari (2004), descriptive research studies are those studies which are concerned with describing the characteristics of a particular individual or of a group. Thus the researcher used descriptive design to determine the natures of variables based on mean and standard deviations and the explanatory design for examining and testing the hypothesis formulated and determines the cause and effect relationship of variables.

The research design identifies the method of data gathering, which instruments used how they are dealt with and how the gathered information is arranged and analyzed. The study utilized cross-sectional survey design in the sense that all relevant data was collected at a single point in time. The reason for preferring a cross-sectional study is due to the vast nature of the study and the limitation of time. In addition, obtaining information from a cross-section of a population at a single point in time is a reasonable strategy for pursuing many descriptive researches (Janet \& Ruane, 2006).

A qualitative and quantitative method of data collection applied to compensate each method's weaknesses with strengths from the other method. The objective of quantitative research was to determine the relationship between an independent variable and a dependent outcome in population numerically (Hopkins, 2008). Quantitative approach which focusing on measuring phenomena by collecting, analyzing numerical data and applying statistic test was used for this research (Hair, Money, Samouel \& Page, 2007). The design of this study was questionnaire survey supported with interview. The researcher collected relevant data through structured questionnaire and face to face interviewing in Flour Manufacturing Companies, in Debre Markos town. Collected data was analyzed using descriptive statistics and inferential analysis. After analyses, result can be presented in the form of tables, charts and graphs.

\subsubsection{Research approach}

According to Ghauri and Kjell (2005), there are two research approaches such as quantitative and qualitative approach, where one of them is not better than the others, all of this depends on how the researcher want to do a research study. The study is conducted using quantitative research approach. The rationale for using quantitative data was to better understand a research problem by numeric values from quantitative research. The objective of quantitative research was to determine the relationship between an independent variable and a dependent outcome in population numerically (Hopkins, 2008). The design of this study was questionnaire survey. Relevant data was collected through structured questionnaire in Flour manufacturing companies, in Debre Markos town. Collected data is analyzed using descriptive statistics and inferential analysis. After analyses, result can be presented in the form of tables, charts and graphs.

On this study, the quantitative research approach was used to explain phenomena by collecting numerical data and analyzing based on mathematical method and applied for examining the cause and effect relationship of variables, and testing of developed hypothesis (Muijs, 2010). The qualitative approach is used to gather insights (beliefs), attitudes and motivations to the personal judgments of employees on total quality management activities in the organization: Flour manufacturing company, in Debre Markos town.

\subsection{Data type and source}

\subsubsection{Data type}

The researcher was used primary data for this study. This data includes objective items that was obtained through the questionnaires and structured interviews. Malhotra, \& Oppenheim (2004) defined primary data as the data originated by the researcher for the specific purpose of addressing the problem at hand. Primary data are original work of research study or raw material without the interpretation that represent an official opinion or position. Hence, primary data are always the most authoritative because the information has not been filtered or interpreted by any second party (Cooper \& Schinder, 2006).

In this regard, the researcher obtained primary data through the method of questionnaire survey from employees. Questionnaire survey provides standardization as all respondents are answering the same questions and from the response of respondent finally lead to analysis (Burn \& Bush, 2010). It has been selected as the preferable way to obtain the primary data, because questionnaire survey is easy to control and transform into statistical information.

\subsubsection{Data source}

Regarding the data source, the study used primary source. The researcher collected Primary source of data through closed ended questionnaires of the 1-5 likert scale (strongly agree to strongly disagree) measurement of the variables which was included on the study. The researcher also obtained the qualitative data through interviews and open ended questions. The researcher collected the data having a directly link with this study, thus providing important information. As this study was basically empirical in nature, the researcher gathered primary data from each company employees and managers. 


\subsection{Sample design}

\subsubsection{Population of the study}

Population is defined as the entire set of individuals or other entities to which study findings can to be generalized (Schutt, 2012). This study population focused on four Flour manufacturing companies in Debre Markos town includes on the following table:-

Table 3. 1: Number of target population for each Manufacturing Company

\begin{tabular}{|l|l|l|}
\hline No & List of Companies & $\begin{array}{l}\text { Target Population } \\
\text { of the study }\end{array}$ \\
\hline 1 & Abat \& Mehari Flour Manufacturing Company & 91 \\
\hline 2 & Tesema, Hilemikael, Biniam, mehari (THBM) Flour Company & 108 \\
\hline 3 & Selam Flour Manufacturing Company & 68 \\
\hline 4 & Gozamen Union (GU) Flour manufacturing Company & 63 \\
\hline \multicolumn{2}{|l|}{ Total } & $\mathbf{3 3 0}$ \\
\hline
\end{tabular}

Source: Own survey on census taken from each the Companies (January, 2021)

3.2.2. Sample size determination

An important decision to be taken while adopting a sampling technique is about the size of the sample. In the determination of sample size, the researcher used the three criteria includes the level of precision, level of confidence or risk and the degree of variability in the attributes are very important and that will measure and enable the researcher to determine appropriate sample size (Bartlett, 2001).

Therefore, based on the preliminary survey of the study, the researcher obtains the total numbers of employees in the manufacturing companies as 330. From this total population, the researcher used Yamane' (1967) formula to calculate sample size.

$$
\mathrm{n}=\frac{N}{1+N(e)^{2}}
$$

Where $\mathrm{n}$ is the sample size, $\mathrm{N}$ is the population size, and $\mathrm{e}$ is the level of precision.

By using the above formula at $95 \%$ confidence level and $5 \%$ level of precision the sample size were obtained as follows:-

$$
\begin{gathered}
\mathrm{n}=330 / 1+330(0.05) 2 \\
\mathbf{n}=\underline{\underline{\mathbf{1 8 0}}}
\end{gathered}
$$

According to Salkind, (2010) proportional sampling refers to a design with total sample size $n$ such that: Proportional sample size from each stratum (company) is calculated by using the following formula:

Where:

$$
\mathrm{ni}=\frac{\mathrm{n} * \boldsymbol{N i}}{N}
$$

$\mathrm{ni}=$ sample size for each company, $\mathrm{Ni}=$ the total number of employees in each Company, $\mathrm{N}=$ the total number of employees in the Company, $\mathrm{n}=$ the total sample size for the company. Accordingly, the table below shows the proportionate sampling for each manufacturing companies based on the above given formula.

Table 3. 2: Proportionate sample distribution for each Manufacturing Company

\begin{tabular}{|l|l|l|l|}
\hline No & List of Companies & $\begin{array}{l}\text { Target Population } \\
\text { of each Stratum }\end{array}$ & $\begin{array}{l}\text { Sample size from } \\
\text { each Stratum }\end{array}$ \\
\hline 1 & Abat \& Mehari Flour Company & 91 & 50 \\
\hline 2 & $\begin{array}{l}\text { Tesema, Hilemikael, Biniam, mehari (THBM) } \\
\text { Flour Company }\end{array}$ & 108 & 59 \\
\hline 3 & Selam Flour Company (GU) Flour manufacturing & 63 & 37 \\
\hline 4 & $\begin{array}{l}\text { Gozamen Union } \\
\text { Company }\end{array}$ & $\mathbf{3 3 0}$ & 34 \\
\hline Total & 68 & $\mathbf{1 8 0}$ \\
\hline
\end{tabular}

Source: Own computation based on census taken from each the Company (January, 2021)

\subsubsection{Sampling technique}

The researcher used proportional stratified sampling technique. Proportional stratified sampling is where the population is divided into subgroups as taking one company as one stratum. A non-overlapping subgroup is a natural set of items. Subgroups might be based on company size, gender or occupation (to name but a few) and the number of participants from each subgroup are determined by their number relative to the entire population (Salkind, 2010).

Based on the overall proportions of the population which was having 330 total target populations, the researcher calculated that how many respondents sampled from each subgroup. This is because of the heterogeneity of the population and all respondents would have equal opportunity of participation. Then to select samples of employees from each subgroup (company), the researcher was used simple random sampling method from a complete list of the different sub companies' employees in Flour Manufacturing in Debre Markos town. 


\subsection{Data collection methods}

Data collection is an important aspect of every type of research. The process of gathering data from selected sample or respondent was begun when the research design has been established (Zikmund, 2010). Inaccurate data collection was lead to invalid results. Therefore, it is vital to decide which type of data should be used for the research. Primary data collection method was adopted for this research. The first hand collected data obtained by survey questionnaire and interview. The collected data was proceed to statistical testing and analyzing after receiving the filed questionnaires from the respondents. As a generic, in this research investigation in order to bring appropriate and pertinent data; researcher employed both questionnaires and interview guide lines. In associated with the data collection tools to be employs, researcher plan to adapt a certain questions from Solomon Gedif (2019) Betremariam Melese (2019), and Mulugeta Kebede (2020) those who carried out their investigation on the effects of total quality management practice on organizational performance. Thereby, researcher taken those questions by modifying in duly that make matched with the specified objectives of the study.

\subsection{Measurement of Variables}

The researcher used top management commitment, employee involvement, customer focus, supplier quality management, continuous improvement, and education and training as the factors of TQM practices based on the literature review. The researcher also included performance factors, namely, employee and customer satisfaction, innovation performance, effectiveness and efficiency of the companies, and production of non-defective products (quality products), to cover non-financial aspects of companies' performance. The study used five-point Likert scale to measure variables since it supports such relationship. The Likert scale in this study considered as categories, not numerical points such as $1=$ strongly disagree, $2=$ Disagree, $3=$ Neutral, $4=$ Agree, $5=$ Strongly Agree which allowed respondents to indicate level of agreement with the statement provided in the questionnaire.

\subsection{Method of data Analysis and Interpretation}

Data analysis refers to examining what has been collected in a survey or experiment and making deductions and inferences. Prior to analysis of the data, the researcher carried out data cleaning. Data cleaning procedure enabled the researcher to spot and eliminate all errors emanating from unclear responses, omission of unwanted data and other related mistakes(Donald and Delno, 2006).

After the researcher collected data from primary source, then the researcher undertaken house editing and coding of raw data and then manually entered in to statistical package for social science (SPSS) version 23 computer software. The researcher applied quantitative methods of data analysis technique. Data that was collected using questionnaire analyzed through descriptive statistics like: frequency, mean, standard deviation and inferential statistical methods such as: correlation and regression for the cause and effect relationship of variables. In descriptive statistical analysis, the researcher used to conduct demographic profile of the study participants and to assess implementation level of total quality management practice. The correlation analysis of this study has been conducted to test the proposed hypothesis whether there is a positive significant relationship between the total quality management practice and organizational performance.

A Bi-variety correlation specifically Pearson's correlation was used to show the relationship and the strength/degree as well as direction of associations between variables that was employed. Multiple linear regression analysis was also employing to find out the predictive power of independent variables (top management commitment, employee involvement, customer focus, supplier quality management, continuous improvement, and education and training) on the dependent variable (organizational performance).

The researcher used regression analyses to determine by how much percent the independent variable or factors of total quality management practice explains the dependent variable which is organizational performance.

The multiple regression models' was applicable as follows:

$\mathrm{Y}=\beta 0+\beta 1 \times 1+\beta 2 \times 2+\beta 3 \times 3+\beta 4 \times 4+\beta 5 \times 5+\beta 6 \times 6+\varepsilon \quad$ Where:

$\mathrm{Y}=$ Dependent Variable (Organizational performance)

$\beta 0=$ constant term; $\beta 1, \beta 2, \beta 3, \beta 4, \beta 5=$ Beta coefficients

$\mathrm{X} 1=$ Top management commitment

$\mathrm{X} 2=$ Employee involvement

$\mathrm{X} 3=$ Customer focus

$\mathrm{X} 4=$ Supplier quality management

$\mathrm{X} 5=$ Continuous improvement

$\mathrm{X} 6=$ Education and training and $\varepsilon=$ the residual value/error term.

After analysis; the finding can be presented in the form of tables, diagrams, and charts by using SPSS (Statistical Package for Social Science) software version 23. Eventually, the researcher offered an interpretations and conclusions as per the obtained data from respondents and informants. 


\subsection{Instrument for validity and Reliability}

One of the methods to test validity, content validity, refers to whether or not the content of the manifest variables (questionnaire) is right to measure the latent concept (total quality management practice, and organizational performance) that the researcher tried to measure (Muijs, 2010). In this study the researcher tried to develop a content-valid constructs by extensive search of literature to select carefully the total quality management practice variables and its effects of measurements of organizational performance.

According to Adams (2007), reliability is a measure for the consistency of collected data through time and among respondents. The researcher tested questionnaire using Cronbach's alpha reliability measurement scales. Alpha values of 0.7 or higher are considered to be adequately reliable. Values between 0.5 and 0.7 are acceptable while values of below 0.5 are considered to be less reliable. A measuring instrument is reliable if it provides consistent results.

As multiple items in all constructs used, the internal consistency/reliabilities of quality management practice assessed with Cronbach's Alpha. Alpha values over 0.7 indicate that all scales can be considered reliable. A questionnaire is said to be reliable if the researcher get same or similar answers repeatedly. According to (Sekaran, 2003) values between 0.50 and 0.80 are acceptable while values below 0.50 are considered less reliable and therefore unacceptable. For in this study, the researcher calculated the cronbach's alpha and the value of it was .766 and was an acceptable value.

\subsection{Research Ethics}

According to Leedy and Ormrod (2010), most ethical issues fall into one of the following four categories; informed consent, confidentiality, security and honesty. Taking in to account this point in concerning ethical consideration, all the information and data from the respondents were confidential, means that it was kept the nature and quality of participants' and no information's was record to link respondents with their responses. The researcher also informed respondents about the aim of the research clearly which was being enabling them to join with full consent. The responses for questionnaire are not exposed to third party but the researcher used them only for academic purpose. And finally the researcher reported the findings in complete honesty.

\section{CHAPTER FOUR}

\section{DATA ANALYSIS AND INTERPRETATION}

\subsection{Introduction}

This chapter presents and analyses the data collected from the respondents. The findings about the relationships and effects of total quality management practice with organizational performance and relevant statistical analysis to answer the research questions was presented and analyzed. To examine the effect of total quality management practices on organizational performance the data collected by using five-point a Likert scale were subjected to analysis. The analysis was carried out by using descriptive, Pearson's correlation and multiple-regression. The results of the analysis are presented using pie-chart, bar graph, table and figures.

\subsection{Response Rate of Respondents}

A total of 180 questionnaires were distributed to employees, 174 were correctly filled and returned, an overall response rate of (96.67\%). According to Rogelberg and Stanton (2007) and Saunders (2007), a response rate of $50 \%$ is adequate; a rate of $60 \%$ is good and a response rate of $70 \%$ and above is very good. Therefore, the response rate in this study was considered to be very good for the study.

\subsection{Reliability Analysis}

A reliable measurement was consistently assigning the same score to the same phenomena. The most common reliability coefficient is the Cronbach's alpha estimates internal consistency based on the average inter - item correlation. The reliability statistic for 52 items based on Cronbach's Alpha was .766 as expressed in Table 4.1. 
Table 4. 1: Cronbach's Alpha's Reliability test for combined variables:

Reliability Statistics

\begin{tabular}{|l|l|l|l|}
\hline Variables & Number of items & $\begin{array}{l}\text { Cronbach's } \\
\text { alpha }\end{array}$ & Comments \\
\hline Top management commitment & 6 & .797 & Accepted \\
\hline Employee involvement & 6 & .785 & Accepted \\
\hline Customer focus & 7 & .766 & Accepted \\
\hline Supplier quality management & 5 & .673 & Accepted \\
\hline Continuous improvement & 7 & .743 & Accepted \\
\hline Education and training & 7 & .851 & Accepted \\
\hline Organizational performance & 14 & .815 & Accepted \\
\hline Total & 52 & .766 & Accepted \\
\hline
\end{tabular}

Source: Own survey, (May, 2021)

Part I: Demographic Data of Respondents

Demographic information described individual profile. The profile section included aspects of sex, age group, level of education, marital status, Area of operation and years of experience.

Pie-chart4.1: Sex of respondents

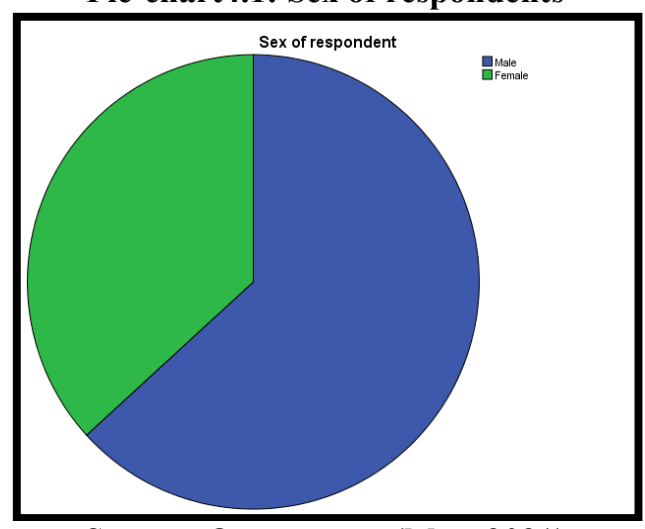

Source: Own survey, (May, 2021)

The above chart 4.1 shows that, $110(63.2 \%)$ of respondents are male, and 64(36.8\%) of respondents are female. This indicates that the numbers of male employees are greater than female employees in the organization. From this the researcher infers that the organization didn't encourage female employees to work in the organization with compared to males even if low participation of females were the problem of Ethiopia. Low participation of females in the organization is not the problem of specifically Flour Manufacturing Company only, but the problem of the whole country in Ethiopia. This problem can be alleviated through hiring of female employees in the organization and encourage them to do their job.

Table 4. 2: Respondents response on level of education and marital status

\begin{tabular}{|l|l|c|c|c|}
\hline \multicolumn{2}{|c|}{ Factors } & Frequency & $\begin{array}{c}\text { Valid } \\
\text { Percent }\end{array}$ & $\begin{array}{c}\text { Cumulative } \\
\text { Percent }\end{array}$ \\
\hline \multirow{4}{*}{ Level of education } & Diploma/certificate & 62 & 35.6 & 35.6 \\
\cline { 2 - 5 } & First degree & 92 & 52.9 & 88.5 \\
\cline { 2 - 5 } & Second degree and above & 20 & 11.5 & 100.0 \\
\cline { 2 - 5 } & Total & $\mathbf{1 7 4}$ & $\mathbf{1 0 0 . 0}$ & \\
\hline \multirow{5}{*}{ Marital status } & Single & 78 & 44.8 & 44.8 \\
\cline { 2 - 5 } & Married & 73 & 42.0 & 86.8 \\
\cline { 2 - 5 } & Divorced & 18 & 10.3 & 97.1 \\
\cline { 2 - 5 } & Widowed & $\mathbf{1 7 4}$ & $\mathbf{1 0 0 . 0}$ & 100.0 \\
\cline { 2 - 5 } & Total & & & \\
\hline
\end{tabular}

Source: Own survey, (May, 2021)

As indicated in table 4.2 , it showed clearly almost half of the participants are possessed bachelor degree (52.9\%). Diploma holders are $35.6 \%$ and second degree and above are $11.50 \%$. Respondents with level of college diploma were of $35.6 \%$. Therefore, this implies that the majorities of respondents are well educated and had the ability to understand the questions they were presented with in regard to total quality management implementation practices.

As also indicated in table 4.2, in regarding to marital status, the majority (44.8\%) of respondents found to be 
single and this is followed by married (42\%). In addition to this, widowed and divorced respondents have accounted $10.3 \%$ and $2.9 \%$ respectively.

Table 4. 3: Respondents response on area of operation and work experience

\begin{tabular}{|c|c|c|c|c|}
\hline \multicolumn{2}{|r|}{ Factors } & Frequency & Valid Percent \% & Cumulative Percent \% \\
\hline \multirow{7}{*}{$\begin{array}{c}\text { Area of } \\
\text { operations }\end{array}$} & Finance & 25 & 14.5 & 14.5 \\
\hline & Strategy and operation & 24 & 14.0 & 28.5 \\
\hline & Human resource & 30 & 17.4 & 45.9 \\
\hline & Marketing & 24 & 14.0 & 59.9 \\
\hline & Production & 51 & 29.7 & 89.5 \\
\hline & Other & 18 & 10.5 & 100.0 \\
\hline & Total & 172 & 100.0 & \\
\hline \multirow{7}{*}{$\begin{array}{c}\text { Work } \\
\text { experience }\end{array}$} & System & 2 & & \\
\hline & Total & 174 & & \\
\hline & Under 1 year & 15 & 8.6 & 8.6 \\
\hline & 1 to 3 year & 70 & 40.2 & 48.9 \\
\hline & 3 to 6 year & 67 & 38.5 & 87.4 \\
\hline & Over 6 year & 22 & 12.6 & 100.0 \\
\hline & Total & 174 & 100.0 & \\
\hline
\end{tabular}

\section{Source: Own survey, (May, 2021)}

As indicated in table 4.3 , the majority of respondents $(29.7 \%)$ were operated in production and $17.40 \%$ of respondents were worked in human resource management. The remaining $14.5 \%$ were finance, $14 \%$ were marketing, $14 \%$ were also strategy and operation and $10.5 \%$ were others like packing operator, operator, formulation expert, and quality manager in the organization.

As also shown in Table 4.3, a large number of respondents work experience lies between 1 to 3 years $(40.2 \%)$, followed 3 to 6 years $(38.5 \%)$ and above 6 years $(12.6 \%)$. Only few respondents work experience is less than 1 years $(8.6 \%)$. Therefore, since majority of respondents lie above 1 to 3 years of work experience, this shows that the respondents are well knowledgeable about overall activities of their company and its organizational performance.

\section{Figure 4. 1: Age description}

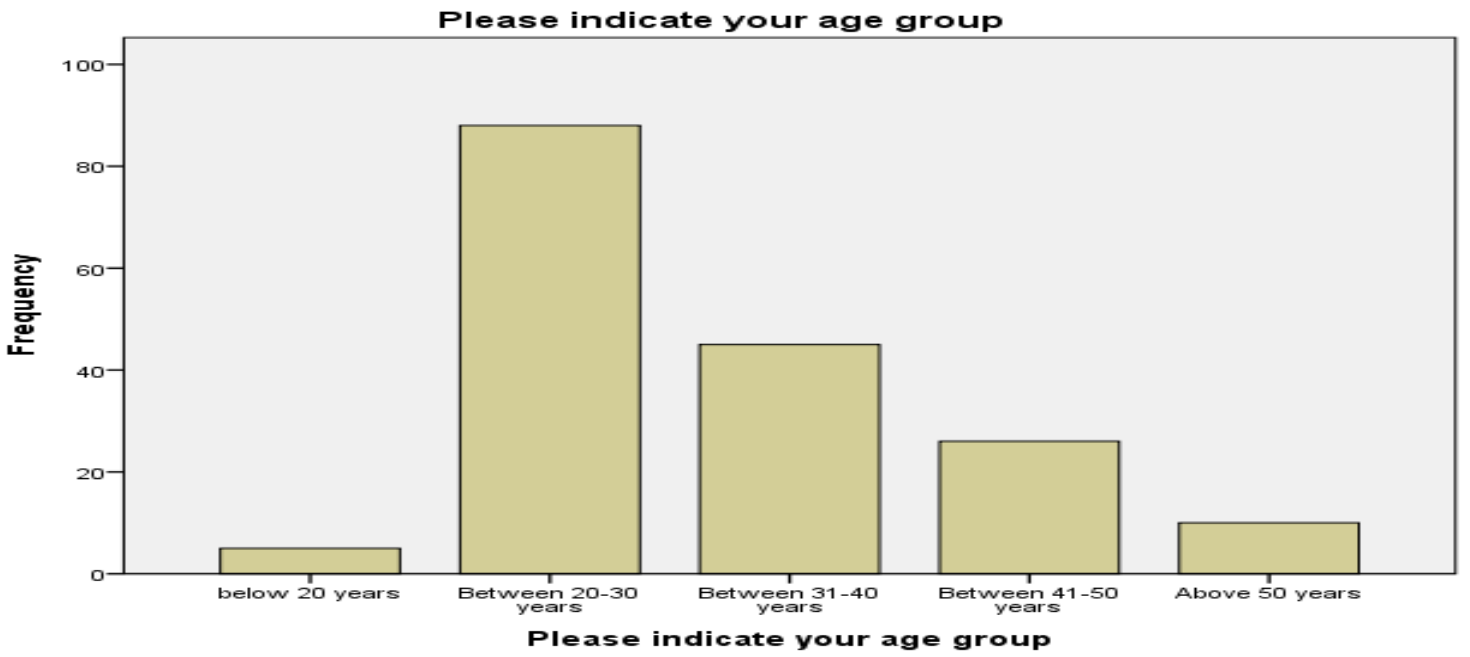

Source: Own survey, (May, 2021)

The above bar graph 4.1 indicates that, $5(2.9 \%)$ of respondents are age groups below 20 years, $88(50.6 \%)$ of respondents are between $20-30,45(25.9 \%)$ are between $31-40$, and $26(11.9 \%)$ of respondents are between $41-50$ and $10(5.7 \%)$ were above 50 years. The above illustration implies that majority employees of the organization were young with age range $20-30(50.6 \%)$ and this would enhance the organization to have energetic and experienced employees to accomplish their organizational goals.

\subsection{Descriptive statistics}

\subsection{Descriptive statistical analysis for TQM factors and the extent of TQM implementation questions} Research question \#1

What are the factors that affect total quality management practice for the performance of the organization in Flour Manufacturing Companies in Debre Markos town? 
Table 4. 4: Factors of total quality management practice

\begin{tabular}{|l|c|c|c|}
\hline Factors & Frequency & Valid Percent & Cumulative Percent \\
\hline Lack of commitment from management & 17 & 9.8 & 9.8 \\
\hline Low staff participation & 13 & 7.5 & 17.2 \\
\hline Problem of supplier quality management & 52 & 29.9 & 47.1 \\
\hline Lack of continuous improvement & 33 & 19.0 & 66.1 \\
\hline Lack of customer attention & 59 & 33.9 & 100.0 \\
\hline Total & $\mathbf{1 7 4}$ & $\mathbf{1 0 0 . 0}$ & \\
\hline
\end{tabular}

Source: Own survey, (May, 2021)

Answer to research question\#1

Explanation: on the above table 4.4 notice that option- 5 or lack of customer attention. The frequency analysis result for factors of total quality management practice indicates that 59 out of 174 respondents own lack of customer attention. This can be considered major factor of total quality management practice which affect organizational performance.

Research question \#2

To what extent total quality management practice is implemented in your company

Table 4. 5: Degree of total quality management implementation

\begin{tabular}{|l|l|l|l|l|}
\hline Factors & Frequency & Valid Percent \% & Cumulative Percent \\
\hline \multirow{3}{*}{$\begin{array}{l}\text { Degree of total quality } \\
\text { management implementation }\end{array}$} & Low & 85 & 48.9 & 48.9 \\
\cline { 2 - 5 } & very low & 8 & 4.6 & 53.4 \\
\cline { 2 - 5 } & Medium & 13 & 7.5 & 60.9 \\
\cline { 2 - 5 } & High & 54 & 31.0 & 92.0 \\
\cline { 2 - 5 } & very high & 14 & 8.0 & 100.0 \\
\cline { 2 - 5 } & Total & 174 & 100.0 & \\
\hline
\end{tabular}

Source: Own survey, (May, 2021)

Answer to research question\#2

Explanation: on the above table notice that option-1 or low implementation practice of total quality management in the organization. The frequency analysis result for degree of implementation of total quality management practice indicates that 85 out of 174 respondents own low implementation practice. This can be considered low implementation practice of total quality management which affects organizational performance.

\subsection{Inferential analysis}

4.5.1. Analysis of association

4.5.1.1. Correlation analysis of TQM practices and organizational performance

According to Robert \& Richard, (2008); Field, (2009) All the relationship that exist between all variables presented and interpretation given based on assumption of correlation values between 0 and $0.3(0$ and -0.3$)$ indicate a weak positive (negative) linear relationship, Values between -0.3 and $-0.7(0.3$ and 0.7$)$ indicate a moderate positive (negative) linear relationship and values between 0.7 and $1.0(-0.7$ and -1.0$)$ indicate a strong positive (negative) linear relationship. Therefore, in this study all correlation results were interpreted in light of this rule.

Table 4. 6: Pearson Correlation between TQM practices and organizational performance

\begin{tabular}{|c|c|c|c|c|c|c|c|c|}
\hline \multicolumn{9}{|c|}{ Correlations } \\
\hline \multicolumn{2}{|l|}{ Variables } & TMC & EI & $\mathrm{CF}$ & SQM & $\mathrm{CI}$ & EDUT & OP \\
\hline Top management commitment & Pearson Correlation & 1 & & & & & & \\
\hline Employee involvement & Pearson Correlation & .064 & 1 & & & & & \\
\hline Customer focus & Pearson Correlation & $.175^{*}$ & $.198^{* *}$ & 1 & & & & \\
\hline Supplier quality management & Pearson Correlation & $.281^{* *}$ & .129 & $.187^{*}$ & 1 & & & \\
\hline Continuous improvement & Pearson Correlation & $.282^{* *}$ & .064 & $.221^{* *}$ & .034 & 1 & & \\
\hline Education and training & Pearson Correlation & .057 & .143 & .049 & -.062 & $.351^{* *}$ & 1 & \\
\hline \multirow{3}{*}{ Organizational performance } & Pearson Correlation & $.365^{* *}$ & $.218^{* *}$ & $.502 * *$ & $.506^{* * *}$ & $.347^{* *}$ & $.189^{*}$ & 1 \\
\hline & Sig. (2-tailed) & .000 & .004 & .000 & .000 & .000 & .013 & \\
\hline & $\mathrm{N}$ & 174 & 174 & 174 & 174 & 174 & 174 & 174 \\
\hline
\end{tabular}

Source: Own survey, (May, 2021)

To determine the relationship between dependent and independent variables, Pearson correlation was computed. Table 4.13 above presents the results of Pearson correlation on the relationship between organizational Performance and its independent variables (top management commitment, employee involvement, customer focus, supplier quality management, continuous improvement, and education and training) are linear and positive ranging 
from medium positive to substantial correlation coefficients.

As the above correlation table 4.13 illustrates that, Organizational performance has statistically significant and moderate positive correlation with continuous improvement and top management commitment at $\mathrm{r}=0.347$, and 0.365 respectively with significant level of $\mathrm{p}<0.001$. And organizational performance has slightly good and to some extent low correlation with employee involvement and education and training at $\mathrm{r}=0.218$ and 0.189 with significant level of $p=0.004$ and $p=0.013$ respectively. Lastly but not the least, supplier quality management and customer focus has strong positive correlation with organizational performance at $r=0.506$ and 0.502 significantly at $\mathrm{p}<0.001$.

\subsection{Hypotheses testing for the relationship of variables}

The researcher was tried to reach conclusions that extended beyond the immediate data provided by descriptive statistics. To go through this, hypothesis testing as one of the method of inferential statistics was used. The researcher has developed six hypotheses that were subjected to test by Pearson correlation. Hypotheses were developed based on study objectives in Flour manufacturing companies.

The third and fourth research questions are intended to determine the relationship between TQM practices and organizational performance as well as effects of TQM practice on organizational performance. In this regard, Pearson correlation has been used in order to determine whether there is significant relationship between TQM practices dimensions and organizational performance. Accordingly, from the above table 4.13 describe the Pearson's correlation coefficient between TQM practices and Organizational performance, which is found using the SPSS. As the result indicates, all TQM Practices, namely top management commitment (TMC), employee involvement (EI), customer focus (CF), supplier quality management (SQM), continuous improvement (CI) and education and training (EDUT) have significant and positive association with organizational performance (OP) in Flour manufacturing companies. Therefore, it implies that the proper implementation of TQM practices enhance organizational performance and vice versa.

\subsection{Regression Analysis of TQM Practices and organizational performance}

The multiple regression analysis was conducted using the hierarchical regression method. It is conducted to investigate the influence of independent variable on the dependent variable and identify the relative significant influence. Before applying the multiple linear regression model assumptions of some tests have been checked. The proposed hypotheses were tested using multiple regression analysis. The results of the regression analysis are depicted on table 4.14 .

\section{Checking assumptions for multiple regression model}

According to Gujarati, (2004), before running regression analysis, it is necessary to assess whether the collected data violate some key assumptions of regression models as any assumption violations can result in unclear and biased research results. To test multiple regression models, first the classical assumptions would be tested. It should be noted that the three classic assumptions must be tested in undertaking the regression analysis. These assumptions include Normality, Multi-colinearity and Autocorrelation (Brooks, 2008).Therefore, in this section, the study have tried to make sure that whether these assumptions are met.

\section{Normality test}

According to Gujarati, (2004), in testing the normality assumption, three tests of normality could be considered: (1) histogram of residuals; (2) normal probability plot (NPP), a graphical device; and (3) the Jarque-Bera test (it is an asymptotic, or large-sample, test). As indicated below, because of their simplicity, the first two simple graphical instruments for testing the normality assumption were applied in this study.

\section{A. Histogram of Residuals:}

A histogram of residuals is a simple graphic device that is used to represent the shape of the Probability Density Function of a random variable. If the residuals are normally distributed around its mean of zero the histogram is a bell-shaped. The shape of the histogram as shown below in figure 6 reflects that the residuals are normally distributed around its mean of zero.

\section{B. Normal Probability Plot:}

In the normal p-p plot points would lie in a reasonably straight diagonal line from bottom left to top right. This would suggest no major deviations from normality. It uses values of the variable of interest on the horizontal axis and the expected value of this variable on the vertical axis. If the fitted line in the NPP is approximately a straight line, one can conclude that the variable of interest is normally distributed. Hence, figure 4.2 below indicated that residuals from the research model regression are approximately normally distributed, because a straight line gives the impression to fit the data reasonably well. This test also shows the normal distribution of residuals around its mean of zero.

Therefore, it is possible to conclude that the normality assumption is fulfilled and the presumption that would make in the study about the population parameter from the sample is suitable. 


\section{Multi-colinearity}

Multi co linearity exists when there is a strong correlation between two or more predictors in the regression model. Perfect colinearity exists when at least one predictor is a perfect linear combination of the other (Guajarati, 2004).There are various methods to produce a co linearity diagnostics and one of which is the variance inflating factor (VIF). The VIF indicates whether a predictor has strong linear relationship with the other predictor(s). As a rule any variables with a value above 10.0 of VIF indicate the multi-colinearity problem (Hair, 1998). The other is the tolerance statistics, which is the reciprocal of VIF.

An insignificant tolerance value indicates that the variable under consideration is almost a perfect linear combination of the independent variables already in the equation and that it should not be included to the regression equation. Tolerance ranges from zero to one. Any variables with a tolerance value below 0.10 or the closer the tolerance value to zero indicates a level of Multi-colinearity. On the other hand, the closer Tolerance is to 1, the greater the evidence that a variable is not collinear with the other repressor (Guajarati, 2004).

Table 4. 7: Collinearity statistics

\begin{tabular}{|l|c|c|}
\hline \multirow{2}{*}{ Variable } & \multicolumn{2}{|c|}{ Collinearity Statistics } \\
\cline { 2 - 3 } & Tolerance & VIF \\
\hline (Constant) & & 1.188 \\
\hline TMC & .842 & 1.074 \\
\hline EI & .931 & 1.128 \\
\hline CF & .887 & 1.133 \\
\hline SQM & .883 & 1.283 \\
\hline CI & .779 & 1.173 \\
\hline EDUT & .852 & \\
\hline
\end{tabular}

Source: Own survey, (May, 2021)

In this study SPSS regression results table 4.14 shows that tolerance for all independent variables is more than 0.10 and variance inflation factor (VIF) for the independent variables is less than the limited value, 10.0. As a result the researcher concluded that there is no multi-colinearity problem between the independent variables.

\section{Homoscedasticity}

Homoscedasticity is the other major assumptions of statistical analyses for multiple regressions. In the analysis of variance (ANOVA), with one quantitative dependent variable (Y) and one or more categorical independent variables (X), the homoscedasticity assumption is known as homogeneity of variance. In this context, it is assumed that equal variances of the dependent variable exist across levels of the independent variables. The data has showed homoscedasticity, where the variances along the line of best fit remains similar as move along the line.

In all of the above tests the given assumptions for the regression model have met. So this study has included model summary of the regression, ANOVA statistics and regression coefficients by applying multiple linear regression.

Table 4. 8: Model Summary

\begin{tabular}{|c|c|c|c|c|}
\hline \multicolumn{5}{|c|}{ Model Summary } \\
\hline Model & $\mathrm{R}$ & R Square & Adjusted R Square & Std. Error of the Estimate \\
\hline 1 & $.722^{\mathrm{a}}$ & .521 & .503 & .26669 \\
\hline $\begin{array}{ll}\text { a. } & \text { Pr } \\
& \text { Em } \\
\text { b. } & \text { De } \\
\end{array}$ & $\begin{array}{l}\text { onstar } \\
\text { vemer } \\
\text { lable: }\end{array}$ & $\begin{array}{l}\text { tion and } \\
\text { r quality } \\
\text { ional per }\end{array}$ & $\begin{array}{l}\text { ng, Customer foct } \\
\text { ement, Continuous } \\
\text { ce }\end{array}$ & $\begin{array}{l}\text { management commitmer } \\
\text { ment }\end{array}$ \\
\hline
\end{tabular}

Source: Own survey, (May, 2021)

On table 4.15 shows that $\mathrm{R}$ in this model represents a correlation between the predicted and observed values of the outcome which is $72.2 \%$. So the correlation shows there is strong relationship between variables. The value of $\mathrm{R}$ square tells that independent variables can account $52.1 \%$ variation in organizational performance. Here $\mathrm{R}$ Square may be overestimated and it is better to look for adjusted $\mathrm{R}$ square. The adjusted $\mathrm{R}$ square tells us that independent variables can predict organizational performance by $50.3 \%$. The Standard Error of the Estimate shows that the remaining with the amount of 0.26669 variations would be predicted by other extraneous variables or factors. 
Table 4. 9: ANOVA $^{\text {a }}$ statistics

\begin{tabular}{|l|l|r|r|r|r|c|}
\hline \multicolumn{7}{|c|}{ ANOVA $^{\mathbf{a}}$} \\
\hline \multicolumn{2}{|c|}{ Model } & Sum of Squares & Df & Mean Square & F & Sig. \\
\hline \multirow{3}{*}{1} & Regression & 12.896 & 6 & 2.149 & 30.221 & $.000^{\text {b }}$ \\
\cline { 2 - 8 } & Residual & 11.878 & 167 & .071 & & \\
\cline { 2 - 8 } & Total & 24.774 & 173 & & & \\
\hline
\end{tabular}

a. Dependent Variable: Organizational performance

b. Predictors: (Constant), Education and training, Customer focus, Top management commitment, Employee involvement, Supplier quality management, Continuous improvement

Source: Own survey, (May, 2021)

As table 4.16 indicates, the model summary which specifies organizational performance as a function of TQM practices: top management commitment, employee involvement, customer focus, supplier quality management, continuous improvement, and education and training. From the ANOVA statistics the researcher can understand that from the total number of observation (24.774) the regression model explains 12.896. The remaining 11.878 is not explained by the model. From this the researcher can understand the regression explains most of observation whereas the lesser observations are explained by other extraneous variables. Mean square of the model (regression) represents the average amount of variation explained by the model is 2.149 whereas mean square of the residual is .071 shows the average amount of variation explained by extraneous variables. The F-ratio is 30.221 which is a measure of the ratio of the variation explained by the model and the variation explained by extraneous variables. ANOVA has been used to test the overall fit of the model. This test is significant, at $(\mathrm{F}=30.221, \mathrm{p}<.001)$.

Table 4. 10: Organizational performance coefficients a

\begin{tabular}{|c|c|c|c|c|c|c|c|c|c|c|}
\hline & & & & Co & ficient & & & & & \\
\hline & & $\begin{array}{l}\text { Unstanc } \\
\text { Coeff }\end{array}$ & $\begin{array}{l}\text { rdized } \\
\text { ients }\end{array}$ & $\begin{array}{l}\text { Standardized } \\
\text { Coefficients }\end{array}$ & $\mathrm{t}$ & Sig. & $\begin{array}{r}95 \\
\text { Conf } \\
\text { Interv }\end{array}$ & $\begin{array}{l}\% \\
\text { lence } \\
\text { for } B\end{array}$ & $\begin{array}{c}\text { Colline } \\
\text { Statist }\end{array}$ & \\
\hline & & B & $\begin{array}{l}\text { Std. } \\
\text { Error }\end{array}$ & Beta & & & $\begin{array}{l}\text { Lower } \\
\text { Bound }\end{array}$ & $\begin{array}{l}\text { Upper } \\
\text { Bound }\end{array}$ & Tolerance & VIF \\
\hline 1 & (Constant) & .116 & .254 & & .455 & .650 & -.387 & .618 & & \\
\hline & TMC & .111 & .049 & .132 & 2.264 & .025 & .014 & .207 & .842 & 1.188 \\
\hline & EI & .048 & .044 & .061 & 1.090 & .277 & -.039 & .134 & .931 & 1.074 \\
\hline & $\mathrm{CF}$ & .325 & .053 & .349 & 6.133 & .000 & .220 & .429 & .887 & 1.128 \\
\hline & SQM & .247 & .035 & .398 & 6.972 & .000 & .177 & .317 & .883 & 1.133 \\
\hline & CI & .118 & .041 & .173 & 2.852 & .005 & .036 & .199 & .779 & 1.283 \\
\hline & EDUT & .095 & .046 & .119 & 2.054 & .042 & .004 & .187 & .852 & 1.173 \\
\hline
\end{tabular}

a. Dependent Variable: Organizational performance

b. Independent variable: Top management commitment (TMC), employee involvement (EI), customer focus $(\mathrm{CF})$, supplier quality management (SQM), continuous improvement (CI) and Education and training (EDUT)

Source: Own survey, (May, 2021)

From the above table 4.17 the researcher can understand that top management commitment, customer focus, supplier quality management, continuous improvement, and education and training have significant effect on organizational performance at $\mathrm{P}<0.05$. Furthermore the $\mathrm{t}$ value is greater than 2 and 0 is not between upper and lower bound confidence intervals, which again support these variables, have significant effect on organizational performance. And employee involvement has positive insignificant effect on organizational performance. Here, the hypothesis; H2: employee involvement has positive significant effect on organizational performance was rejected. Whereas hypotheses of $\mathrm{Ha} 1, \mathrm{Ha} 3, \mathrm{Ha} 4, \mathrm{Ha} 5$ and Ha6: has positive significant effect on organizational performance. And the hypotheses were accepted. The objective of the regression in this study was to find such an equation that could be used to find the effect of predictors (independent variables) on dependent variable. The specified regression equation takes the following form:

$\mathbf{Y}=\boldsymbol{\beta 0}+\boldsymbol{\beta 1} \mathbf{x} 1+\boldsymbol{\beta 3} \times \mathbf{3}+\boldsymbol{\beta 4} \mathbf{x} 4+\boldsymbol{\beta 5} \times \mathbf{5}+\boldsymbol{\beta 6} \mathbf{6} 6+\boldsymbol{\varepsilon}$ : since $\mathbf{2} 2$ was not supported, the equation of the model excluded $\mathrm{x} 2 / \mathrm{employee} \mathrm{involvement.}$

\section{$\mathrm{Y}=0.116+0.111 \times \mathrm{TMC}+0.325 \times \mathrm{CF}+0.247 \times \mathrm{xSQM}+0.118 \times C I+0.095 \times E D U T+\varepsilon$}

Where $\mathrm{Y}=$ Organizational performance, $\mathrm{TMC}=$ Top management commitment; $\mathrm{CF}=\mathrm{Customer}$ focus; $\mathrm{SQM}=$ Supplier quality management; $\mathrm{CI}=$ Continuous improvement; EDUT=Education and training and $\mathrm{e}=$ the residual amount.

The Unstandardized coefficients of beta show the effect of independent variables on organizational performance by the given amount in the above table. The regression equation above shows that, by taking all factors into account constant at zero, the organizational performance in the factory will have the value of 0.116 . 
And the findings presented also show that taking all other independent variables at zero, a unit increase in top management commitment increases organizational performance by 0.111 . A unit increase in customer focus increases organizational performance by 0.325 . A unit increase in supplier quality management increases organizational performance by 0.247 . A unit increase in continuous improvement would have increased organizational performance by 0.118 . A unit increase in education and training increases organizational performance by 0.095 . Employee involvement has positive but, insignificant effect on organizational performance.

\subsection{Hypotheses testing in linear regression}

The study's hypothesis testing have been made based on $\beta$, and $\mathrm{P}$ values. Hence using those coefficient results, the proposed hypotheses for this study can be tested as follows.

Ha1: There is a significant and positive relationship between Top Management Commitment and organizational performances.

The results of multiple regressions, as presented in Table 4.17 above, revealed that top management commitment had a positive and significant effect on organizational performance with values $(\beta=0.111, p<0.05)$. Thus, proposed hypothesis was accepted and the above result is supported by the studies of (Javed, 2015)) who found top management commitment as having a positive and significant effect on organizational performance. In this case the beta coefficient describe that keeping the other variables constant, in this model a one $(1 \%)$ change in the overall top management commitment, the consequence would be an increase in organizational performance by $11.6 \%$.

Ha2: There is a significant, positive relashipship between employee involvement and organizational performance. The second hypothesis which stated that employee involvement has a positive and insignificance influence on organizational performance. The results of the multiple regressions, as presented in table 4.17, revealed that employee involvement has a positive and insignificant effect on organizational performance with a beta value (beta $=.048$ ), with $\mathrm{p}>0.05$. Therefore, the hypothesis is not supported.

Ha3: There is a significant, positive relationship between Continuous Improvement andorganizational performance.

The results of multiple regressions, as presented in Table 4.17 above, revealed that customer focus had a positive and significant effect on organizational performance with values $(\beta=0.325$, with $p<0.05)$. Thus, the proposed hypothesis can be accepted.

Ha4: There is a significant, positive relationship between supplier quality management and organizational performance.

As indicated in the table 4.17, supplier quality management has scored a beta value of 0.247 , and $\mathrm{P}$ value is less than 0.05 . Therefore, supplier quality management had a positive and significant effect on organizational performance. Thus, proposed hypothesis is accepted.

Ha5: There is a significant, and positive relationship between customer focus and organizational performance.

As shown in the table 4.17, continuous improvement has beta value of 0.118 , and p-value is less than 0.05 . From this result researcher concluded that continuous improvement has significant impact on organizational performance. Consequently, this hypothesis is accepted.

Ha6: There is a significant and positive relationship between Education and Training with improving organizational performance in flour manufacturing company.

As shown in the table 4.17, education and training has beta value of .095 , and p-value is less than 0.05 . From this result education and training has significant effect on organizational performance. Thus, this hypothesis is accepted.

\subsection{Discussions}

This section deals with discussion of results by linking the effect of total quality management on organizational performance with theories and problems rose initially in problem statement. The response rate of $96.67 \%$ was considered adequate for analysis and the reliability of instrument using Cronbach's alpha was high at .766, which was above the normally accepted .70 for social sciences. The frequency analysis of respondents' area of operation was on the production $51(29.7 \%)$, through adaptation of work but not on quality production satisfying customers need. But quality meant the organization meeting various customers' objectives through identifying their needs (Vassilakis and Besseris, 2009).

The descriptive analysis presented about employees' perception on the major factors of total quality management was lack of customer attention 59 (33.9\%). And following Problem of supplier quality management 52 (29.9\%), and continuous improvement 33 (19\%). Besides, the degree of implementation of total quality management was low 85 (48.9\%). The companies' low degree of implementation of TQM decreases the performance of the organization. But according to Crosby (2009) TQM philosophy and methods can lead to improvement in business and operational performance, such as: improved process yields, motivated employees, satisfied customers, improved quality, productivity and profitability. The scope of performance outcomes, based on quality initiatives, therefore, appears to be very broad. 
Here also on the descriptive analysis, even if top management commitment slightly good, it is not performing in effective and proper manner since the mean score of the respondents show that there is no guarantee on top management commitment whether it was performing effectively or not. They agreed that their companies' top management actively involved for developing a comprehensive plan to improve quality implementation and to meet companies' goals. The highest values belong to this was $(\mathrm{M}=3.5),(\mathrm{SD}=1.095)$; On the contrary the least was, top management acknowledges and rewards employees' contributions to bettering quality having mean $=2.79$ and $\mathrm{SD}=0.953$. This study investigated the effect of top management commitment on organizational performance. According to Ahuja (2009), top management can influence achievement of manufacturing performance advancements. From the findings, this study deduced that the commitment and support of top management towards quality initiatives is vital for organizational performance.

The variable employee involvement, customer focus supplier quality management, continuous improvement and education and training were a moderate result of mean and standard deviation. An overall organizational performance mean score was 3.158 and standard deviation of 0.991. Accordingly, the overall perceptions of the respondents seem to be low; because the aggregate mean score is less than 3.40. The results indicate that majority of the respondents agreed that the companies offers high quality administrative systems are in place to support the efficiency of the organization. This was indicated by the mean score of 3.48 and standard deviation 0.838 .

The correlation analysis result established that all of the constructs of TQM are positively and significantly correlated to each other. This would suggest that the TQM practices complement each other and, therefore, need to be applied in a combined fashion (Agus and Hassan, 2011). Moreover, it was also found that all of the TQM practices are positively and significantly correlated with organizational performance which indicates that an increase in the implementation of TQM practices causes increments in the companies' organizational performance (Zehir, 2012). These the relationship between dependent and independent variables were (TMC $=0.365$ and $\mathrm{sig}=.000),(\mathrm{EI}=0.218$ and $\mathrm{sig}=.004),(\mathrm{CF}=0.502$ and $\mathrm{sig}=.000),(\mathrm{SQM}=0.506$ and $\mathrm{sig}=.000),(\mathrm{CI}=0.347$ and sig $=0.000)$, and $(\mathrm{EDUT}=0.189$ and $\mathrm{sig}=0.013)$.

The regression analysis of the TQM variables; top management commitment, employee involvement, customer focus, supplier quality management, continuous improvement, and education and training as the independent variables on one end and organizational performance revealed $\mathrm{R} 2=.521$, adjusted $\mathrm{R} 2=.503$. These findings reveal that except employee involvement there is a strong positive relationship between total quality management practice and organizational performance. Those who support this study finding were the following. Top management commitment is positively related to the success of quality management in an organization (Javed, 2015), customer orientation is positively associated with firm performance (Asikhia, (2010), supplier quality management has significant and positive relationships with organizational performance (Kaynak, 2003), continuous improvement significantly affects every indicator of the company's organizational performance and thereby increase organizational competitiveness (Kiprotich, 2018), and for training to be effective it should be executed in a situation that employees can rehearse what they have been taught for the enhancement of quality (Bunney and Dale, 1997).

The relationship confirmed positively to this study and significant at $\mathrm{F}=30.221, \mathrm{P}=.000^{\mathrm{b}}$. From the regression result, five out of six predictors of total quality management practice were significant and positively related with organizational performance in Fluor manufacturing companies. But, the significance for employee involvement at .277 however shows no significance relation with organizational performance. The significant relationship however was moderate as revealed from the statistics. The findings further support the earlier descriptive analyses.

\section{CHAPTER FIVE \\ CONCLUSIONS AND RECOMMENDATIONS}

\subsection{Introduction}

This chapter has provided conclusions, recommendation and suggestion for future research. This study examined the effect of TQM practices on organizational performance in Fluor manufacturing companies in Debre Markos town. The causal relationship between TQM practices and organizational performance were discussed through using linear regression model.

\subsection{Conclusions of the study}

The general objective of this study was to examine total quality management practices implementation and their relationship with organizational performance in Flour Manufacturing companies.

The descriptive analysis results for factors of TQM practice were lack of customer attention, as a major factor that affect organizational performance, and its implementation degree of total quality management practice were low as a result. The descriptive statistics also shows that TQM practices (top management commitment, employee involvement, customer focus, supplier quality management, continuous improvement and education and training) have moderate mean and SD values with organizational performance. From these among the major predictor 
variables, customer focus was found to be higher mean score; and customer focus practices affect organizational performance implied that the management of the companies should note that customers are economic assets, and they play a central role on the organization's performance. Today's consumers are highly knowledgeable and demanding. In order to be responsive, competent and successful its better companies to be customer-focused and competition-oriented. The results suggest that focusing on customers is an important strategy for improving performance. If the manufacturing companies focused on timely handling of customer complaints, and having customer feedback systems, this would lead to customer retention and in turn organizational performance. Based on descriptive statistics of this study, it is reasonable to conclude that total quality management practices contributed to performance at Fluor manufacturing companies.

The correlation analysis result established that all of the constructs of TQM (top management commitment, customer focus, supplier quality management, continuous improvement and education and training with companies' performance) are positively and significantly correlated to each other. From the correlation results of the study, supplier quality management and customer focus has strong positive correlation with organizational performance at $r=0.506$ and 0.502 significantly at $p<0.001$. It has been found that supplier quality management is the major predictors of TQM that significantly and positively affects the organizational performance in Flour manufacturing companies. On this result, using quality as an important criterion for selecting suppliers, participating in supplier activities related to quality, and providing feedback on the performance of suppliers' products were the major issues considered under the supplier quality management.

Therefore, managing quality related issues with suppliers can help manufacturing organizations to enhance their performances. On the customer focus result also, the researcher suggest conclusions that focusing on customers is an important strategy for improving performance. If the manufacturing companies focused on timely handling of customer complaints, and having customer feedback systems, this would lead to customer retention. And customer focus were vital to organizations success and superior performance because the study findings shows customer focus was found to positively influence quality management practice on performance at Fluor manufacturing companies.

As the finding indicates, even if all of the constructs of TQM are positively and significantly correlated, not all TQM practices did significantly strong impact on organizational performance. Here like, even though, employee involvement, and education and training correlated at $r=0.218$ and 0.189 significantly at $p<0.004$ and 0.013 respectively. Even though, employee involvement and education and training influences performance positively but there is need for the management allow to uses an extensive employee suggestion system and the company has been implementing training policies for employees in a good manner to foster organizational performance.

Regression analysis results support the findings indicating that the model was significant. As indicated in the regression analysis, customer focus and supplier quality management were the major predictors of performance. The study also further concludes that top management commitment, continuous improvement and education and training were found to be statistically direct significant effect on organization's performance. From this the researcher conclude that customer focus and supplier quality management has the highest contribution on organizational performance, followed by continuous improvement, then top management commitment, and then education and training. However, employee involvement had an insignificant effect on organizational performance.

Generally, the overall findings clearly depict that TQM can significantly affect the organizational effectiveness of Flour manufacturing companies. To this end, hypothesis five out of six have confirmed with the findings. In other words, TQM practices have an impact on employee's satisfaction and profitability. And it is reasonable to conclude generally that total quality management practices positively contribute to the performance of Flour manufacturing companies in Debre Markos town.

\subsection{Recommendations}

The conclusion of the study has revealed that TQM practices have a direct significant effect on organizational performance. The study is also indicated that limitations on the use of employee involvement and management, rewarding mechanisms for those who achieve better and on education and trainings were given less emphasis and are identified as a gap. On the bases of the findings and conclusion of the study, the following feasible recommendations are forwarded.

$>$ Even though the existing situation is fair, the management should improve their effort in considering total quality management as a priority for the efficiency of their companies. This can be realized in the future by involving the company's efficient and effective utilization of the given resource.

$>$ Mostly the companies major factors of total quality management was less attention given for customers, but customer focus have a direct significant effect of organizational performance. So, it is recommending to the companies to great attention to customers, because company existence depends on the customers and therefore should be keen on understanding current and future customer needs to improve performance. 
$>$ Top management should provide employees the required resource (with better resource allocation), training and freedom to act with responsibility and accountability for the creation and sustenance of shared values and fairness at all level of the company so as to improve performance.

$>$ Total Quality improvement activities emerge from a systematic and organized framework for improvement. This framework, can be adopted by the organization's management, understood, accepted and utilized throughout the organization, as a result it is advisable for continuous education and involvement of staff at all levels in performance improvement.

$>$ Finally the researcher recommends the Companies that they should benchmark themselves with the best performing Companies nationally in order to find out the total quality management practices that the companies use in enhancing competitiveness. This will shed more light on the best quality management practices to adapt to increase organizational performance.

\subsection{Suggestions for Future Research}

Although the results of this study only drawn from a Fluor manufacturing companies, nearly the same output, it is acknowledged that differences among manufacturing organizations may impact upon the results, but these are beyond the scope of this research, and those issues could be addressed by further research. This may not be an actual representation of other manufacturers. In addition, comparative studies should be done between manufacturing companies. So, in order to triangulate the findings and make comparison of TQM implementation, further researchers are recommended different manufacturing companies. It is also acknowledged that it would be more informative if objective performance data would have been used instead of using subjective (perceptual measure).Financial performance was not addressed in this research and it could be addressed by future research. Finally, yet importantly, the researchers suggest the consideration of some contextual variables such as, age of the firm, scope of operation, firm size, and firm strategy while addressing the linkage between TQM practices and organizational performance.

\section{Reference}

Adams, R. (2007). Reliability as a measurement design effect. Studies In Educational Evaluation, 31. 162-172.

A.S., B. (2012). Relationship between total quality management and performance of Singapore companies- . International journal of quality and reliability, V.19 pp. 356-375.

Addis, S. (2019). Quality management practices as a tool for job satisfaction improvement of shop-floor workers: empirical evidence from the Ethiopian manufacturing organizations. Production Planning \& Control, Vol. 30 No. 8, pp. 665-681.

Agus, A. (2005). The structural linkages between TQM, product quality performance, and business performance: preliminary empirical study in electronic companies. Singapore Management Review, Vol. 27 No. 1, pp. 87105.

Ahire, L. (2000). The impact of design management and process management on quality: an empirical investigation. Journal of Operations Management, 18(5), 549-575.

Ahuja, I. \&Khamba, J. (2009). Investigation of manufacturing performance achievements through strategic total productive maintenance initiatives. International Journal of Productivity and Quality Management, Vol. 4, No. 2, pp.129-152.

Alemu, M. H. (2011). Effects of quality management practices and concurrent engineering in business performance. International Journal of Business and Management, Vol. 6 No. 3, pp. 45-62.

Anastasia, K. (2008). "Measuring the impact of quality management on organizational performance . Journal of industrial engineering and management.

Anderson, J. (1995). A path analytic model of a theory of quality management underlying the Deming Management Method: preliminary empirical findings . Decision Sciences , 26, 637-658.

Arauz, R. (2004). ISO 9000 performance in Japanese industries. TotalQuality Management and Business Excellence, 15(1), pp. 3-33.

Arend, R. \&Levesque, M.(2010). Is the resource-based view a practical organizational theory"? . Organization Science, Vol. 21(4), 913-30.

Armstrong, K. (2006). Structural Empowerment, Magnet Hospital Characteristics, and Patient Safety Culture. Journal of Nursing Care Quality, 21(2), 124-132.

Arnold, M. (2014). Continuous Improvement and Operational Performance of Small and Medium Sized Manufacturing Firms in Kenya. The University of Nairobi.: MBA Thesis.

Asikhia, O. (2010). Customer Orientation and Firm Performance among Nigerian Small and Medium Scale Businesses. International Journal of Marketing Studies, 2(1), 197-205.

BIBLIOGRAPHY Bajaj, S. (2018). Total quality management: a critical literature review using Pareto analysis . International Journal of Productivity and Performance Management, Vol. 67 No. 1, pp. 128-154.

Barney, J. (1991). Firm resources and sustained competitive advantage. Journal of management, 17(1), 99-120. 
Barney, J. (2001). Is the resource-based view a useful perspective for strategic management research? Yes. . Academy of Management Review, 26: 41-54.

Barney, J. (2010). Strategic management and competitive advantage concept. Upper saddle River, N.J: Pearson Prentice Hall.

Bass, B. (1990). From transactional to transformational leadership: Learning to share the vision. Organizational dynamics, 18(3), 19-31.

Bartlet, J. (2001). Organizational Research: Determining Appropriate Sample Size in Survey Research. Learning and Performance Journal, 19, 43-50.

Besterfield, D. M. (2014). Total Quality Management. USA: Pearson Education.

Besterfield, H. (2001). Total quality management (6th ed.). London: Prentice-Hall.

Bethelhem, M. (2019). The Effect of Total Quality Management on Organizational Effectiveness. The Case of Nile Insurance Company S.C, AA, AAU, PP.50-53.

Bhat, K. (2009). An Empirical Study of Barriers to TQM Implementation in Indian Industries . The TQM Journal, 21(3), 261-272.

Birhanu, B. a. (2014). Quality management practice in Ethiopia. African Journal of Business Management, Vol. 8 No. 17, pp. 689-699.

Boukmeish, A. (2010). Total Quality Management ISO - 9000. Al -Raya Publishing.

Bryman, A. ( 2003). Business Research Methods. USA: Oxford University Press.

Burns, C. \&. Bush, F. (2010). Marketing Research, 6th Edition. University of West Florida: Pearson: Publishing as Prentice Hall.

Chin, K. \&. Choi, T. (2003). Construction in Hong Kong: success factors for ISO 9000 implementation . Journal of Construction Engineering and Management, Vol. 129 No. 6, pp.599-609.

Chuang, H. \&. Lin, N. (2017). Performance implications of information-value offering in eservice systems: Examining the resource-based perspective and innovation strategy. The Journal of Strategic Information Systems, 26(1), 22-38.

Cooper, D. (2006). Business research methods. . New York: McGraw-hill .

Cooper, G. (2005). Benchmarking best NPD practices-Part 3: The NPD process \& decisive idea-to-launch activities. Research-Technology Management , 47 (6): 43 - 55.

Crosby, D. (2009). What Should The Quality Manager Do? . New York: Mc Graw Hill.

Dale B. (2003). Total quality management adoption: Revisiting the levels. The TQM Magazine, 9(6), pp 418 - 428.

Dalton, M. (2009). what's constraining your innovation? Research-Technology Management, 52(5): 52-64.

Daniel, K. a. (2003). Quality management efforts and problems in Ethiopian manufacturing industries. Journal of EEA, Vol. 20, pp. 55-74.

David L. (2014). Quality Management for Organizational Excellence:Introduction to Total Quality, Seventh Edition. England : Pearson Education.

Dean, J. \&.Bowen (1994). Management theory and total quality: . Improving research and practice through theory development. Academy of Management Review , 19 (3) 392-418.

Deming, W. (1986). Out of Crisis. , M. A. . Cambridge: MIT Centre for Advanced Engineering Study.

Donald, K. (2006). Project and thesis writing; An Introduction. Africa: Paulines Publications.

Engel, R. (2014). Fundamentals of social work research.2nd Ed. . Sage Publications, Inc.

Escrig-Tena, A. (2004). TQM as a Competitive Factor: A Theoretical and Empirical Analysis. International Journal of Quality \& Reliability Management, 21(6), 612-637.

Fassoula, D. (2006). Transforming the supply chain. Journal of Manufacturing Technology Management, 17(6), pp. 848-60.

Freeman-Bell, G. (1994). The Costs and Benefits of Quality Management Certification for Local Authorities. Quality World, 818-823.

Gregory, N. and Noel P. (2000). Enterprise logistics and supply chain structure. The role of fit Journal of Operation Management, 18, 531-547.

Gaudreau, B. \&Meyerson.D. (2012). Effect of empowerment on employees performance . Advanced research in economic and management sciences, vol. 2, 40-46.

Ghauri, P. \& Kjell, G. (2005). Research Methods in Business Studies (4th Edition). UAS: Pearson.

Gitlow, H. (2000). Quality Management Systems: A Practical Guide. Washington DC: CRC Press.

Goetsch, D. (2010). Quality Management for Organizational Excellence, 6th edition. NJ, USA: Pearson New Jersey.

Goldratt, E. (1990). What is this thing called the Theory of Constraints. North River Press, and Croton-on-Hudson, NY.

Goldratt, E. (1984). The Goal:Croton-on-Hudson . NY: the North River Press.

Gupta, M. (2002). Theory of Constraints-based performance measures and five focusing steps in a job-shop manufacturing environment. International Journal of Production Research , 40(4): 907-990. 
Hackman, J. (1995). Total quality management: empirical, conceptual and practical issues. Administrative Science Quarterly, Vol. 40, pp. 309-42.

Haile, Y. Raju A. (2016). The extent of TQM practices in Ethiopian manufacturing firms: an Empirical Evaluation. International Journal of Applied Research, Vol. 2 No. 5, pp. 238-244.

Helper, S. \&Kiehl, J. (2004). Developing supplier capabilities: Market and non-market approaches. Industry \& Innovation, 11(1/2), 89-107.

Hitt, M.Ireland, R., \& Hoskisson, R. (2013).Strategic Management: Competitiveness \& Globalisation (11 ed.). Stamford: Cengage Learning.

Hockman, K. (2004). Road map to ISO 9000 registration. Quality Progress, Vol. 27 No. 5, pp. 39-42.

Hoyle, D. (2007). (), “Quality Management Essentials. Tokyo: Routledge.

Hsu, C. \&Pereira, A. (2008). Resource View Theory Analysis of SAP as a Source of Competitive advantage for Firms. the DATA BASE for Advances in Information Systems, pp. 38-4.

Hubert. (2005). Managing Total Quality, Enhancing Personal and Firms value. Tata Me Grawhil: New Delhi, pp. $127-158$

Inman, R. (2009). Analysis of the relationships among TOC use, TOC outcomes, and organizational performance. International Journal of Operations and Production Management, 29(4): 341-356.

Innocent, O. (2015). The Performance of Commercial Banks: The Role of Organizational Culture as a Mediator and External Environment as a Moderator (Unpublished doctoral dissertation). Malaysia: Universiti Utara .

Irfan, M. \&Kee, D. (2013). Critical success factors of TQM and its impact on increased service quality: A case from service sector of Pakistan. Middle East Journal of Scientific Research , 15(1), 61- 74.

Janet, M. \&Ruane, J. (2006).Essentials of Research Methods. A Guide to Social Science Research. USA: Blackwell Publishing.

Javed, S. (2015). Impact of Top Management Commitment on Quality Management. International Journal of Scientific and Research Publications, Volume 5, Issue 8.

Jonsdottir, S. (2014). Continuous improvement projects in certified organizations in Iceland: traditional projects or not?. . Procedia-Social and Behavioral Sciences, 119, 142-151.

Juda, M. (2014). Total Quality Management Concepts and Applications. Oman Jordan: Dar Wael Publishing.

Kemboi, M. (2016). Quality Management Dimensions and Customer Service Excellence MBA Thesis. Juja: Jomo Kenyatta University of Agriculture and Technology,

Kim,S.(2009).Aninvestigationonthedirectandindirecteffectofsupplychainintegrationonfirmperformance International Journal of Production Economics , 119, 328-346.

Kiprotich, A. (2018). Total quality management practices and operational performance of Kenya revenue authority. International Journal of Contemporary Aspects in Strategic Management, Vol. 2 pp. 91-105.

Lakhal, L. Pasin, F. \&Limam, M. (2006). Quality management practices and their impact on performance. International Journal of Quality and Reliability Management.

Lamport, M. (2014). The association between ISO 9000 certification and financial performance . International Research Symposium in Service Management, Mauritius.

Leedy P. \& Ormrod J. (2010).Practical research: planning and design (9th edition). Upper

Saddle River, NJ: Pearson.

Li, S. (2006). The impact of supply chain management practices on competitive advantage and organizational performance. Omega, 34(2), 107-124.

Liu, S. (2002). Integrating customer orientation, corporate entrepreneurship, and learning orientation in organizations-in-transition: An empirical study . International Journal of Research in Marketing, 19(4), 367382.

Lummus, R. (2003). The impact of marketing initiatives on the supply chain. Supply Chain Management: An International Journal, 8 (4), 317-323.

Makadok, R. (2001). Toward a synthesis of the resource-based and dynamic-capability views of rent creation. Strategic Management Review, 22.

Malhotra, N. (2004). Marketing research: an applied orientation, 4th edition. London: Prentice-Hall International.

Mann, R. (2009). Factors affecting the implementation and success of TQM. International Journal of Quality and Reliability Management , 12 (1), 11-23.

Masindet, E. (2014). Influence of Total Quality Management Practices on Supply Chain Performance of Cement Manufacturing Firms in Kenya. European Journal of Business Management, 1(11), 181-197.

Muijs, D. (2010). Doing Quantitative Research in Education with SPSS, Second Edition. New Delhi: SAGE Publications.

Mulugeta K. (2020). The effect of TQM practices on operational performance . An empirical analysis of ISO 9001 : 2008 certified manufacturing organizations in Ethiopia, pp.30-32.

Oakland, J. (2000). Total Organizational Excellence, Butterworth-Heinemann, Oxford, Fifth Discipline Resource. London: The Dance of Change, Nicholas Brearley. 
Oakland, J. (2004). Total Quality Management. Oxford Butterworth: Heinemann On business .

Obeidat, A. (2018). The role of organisational culture in enhancing the human capital applied study on the social security corporation. International Journal of Learning and Intellec.

Olepein, R. (2015). Quality Management Systems and Organization Performance. Nairobi: MBA Thesis Jomo Kenyatta University.

Olepein, R. (2015). Quality Management Systems and Organization Performance”, MBA Thesis, Jomo Kenyatta University, Nairobi. performance. International Journal of Quality and Reliability Management, Vol. 2, pp. $135-144$

Palmatier, R. (2014). Resource-Based Theory in Marketing. Journal of the Academy of Marketing Science, 42(1), $1-21$.

Pheng, L. (2004). Implementing Total Quality Management in Construction Firms . Journal of Management in Engineering, 20(1), 8-15.

Prajogo, D. (2003). The relationship between TQM practices, quality performance, and innovation performance, an empirical examination. International Journal of Quality and Reliability Management, Vol. 20, No. 8, pp. 901-918.

Qureshi, M. (2011). Study of performance measurement practices in supply chain management. International Journal of Business, Management and Social Sciences, Vol. 2, No. 4, 2011, pp. 19-34.

Ramamoorthy, S. (2007). Lean Six Sigma Applications in Aircraft Assembly. Thesis Report.

Ronald, F. (2010). Amman.Burns, Alvin C. and Marketing Research, 6th Edition, textbook and instructor's manual. Pearson Education, Inc: publishing as Prentice Hall.

Ruane, J. (2006). Essentials of Research Methods. A Guide to Social Science Research . USA: Blackwell Publishing.

Salah, A. (2018). Total quality management practices and performance of commercial banks in Garissa County, Kenya. International Academic Journal of Human Resource and Business Administration, Vol. 3 No. 1, pp. 52-67.

Salaheldin, S. (2009). Critical success factors for TQM implementation and their impact on Performance of SMEs . International Journal of Productivity and Performance Management, Vol. 58 No. 3, pp. 215-237.

Samat, N. (2006). TQM practices, service quality, and market orientation - some empirical evidence from a developing country. Management Research News, Vol. 29, No. 11, pp.713-728.

BIBLIOGRAPHY Sekaran, U. (2003). Research Methods for Business: A Skill-Building Approach. 4th Edition . New York: John Wiley \& Sons.

Shahin, A. \&Dabestani, R. (2011). A feasibility study of the implementation of total quality management based on soft factor . Journal of Industrial Engineering and Management, 4(2), 258- 280.

Solomon, G. (2019). Assessment of Quality Management Practices and Organizational Performance. The case of Modern Building Industries P.L.C (MBI), pp.50-52.

Suarez J. (1992). Three experts on quality management: philip B. Crosby, W. Edward Deming and Josef, M. Joran : No. 92-02. TQLO publication.

Sugannthi, L. \&Samuel, A. (2015).Total Quality Management . New Delhi: Asoke K. Ghosh

Sureshchandar, G. (2001). A Holistic Model for Total Quality Service . International Journal of Service Industry Management, 12, 378-412.

BIBLIOGRAPHY Tessema, B. (2008). "Quality related problems in large Ethiopian manufacturing firms: implications for competency. South African Journal of Industrial Engineering, Vol. 18 No. 1, pp. 53-75.

Thakkar, J. (2006). Total quality management(TQM) in self-financed technical institutions: a quality function deployment (QFD) and force field analysis approach. Quality Assurance in Education, Vol. 14 No. 1, pp. 5474.

Titi, K. (2010). Knowledge Management: Challenges, Techniques. Da r: Al-Hamed Publishing and Distribution.

Vassilakis, E. \&. (2009). An Application of TQM Tools at a Maintenance Division of a Large Aerospace Company . Journal of Quality in Maintenance Engineering, 15(1), 31-46.

Venkatraman, N. \&Ramanujam, V. (1986). Measurement of business performance in strategy research: A comparison of approaches . Academy of Management Review, 11: 801-814.

Wahid, R. (2009). Critical success factors and problems in ISO 9000 maintenance. International Journal of Quality and Reliability Management, 26 (9): 881-93.

Williams, A. (2006). Economics, QALYs and medical ethics-A health economist's perspective. Health Care Analysis , 3, (3): 221-6.

Yamane. (1967). Statistics, an introductory analysis, 8nd ed., determining sample size. New York: Harper and Row, Cited in Israel: University of Florida.

Zadry, H. \&Yusof, S. (2007). Total quality management and theory of constraints implementation in Malaysian automotive suppliers . Total Quality Management, 17, 999- 1020. 
Zhang, Z. (2000). Developing a model of quality management methods and evaluating their effects on business performance . Total Quality Management, 11(1), 129-37.

Zikmund, W. (2010). Business Research Methods . South-Western: Cengage.

Zikmund, W. (2003). Business Research Methodology. 7th ed. United States: South Western.

$\mathrm{Zu}$, L. (2006). The evolving theory of quality management: the role of Six Sigma. Journal of Operations Management, vol. 26, no. 5, pp. 630-650.

\section{Appendix-1: Histogram of residuals}

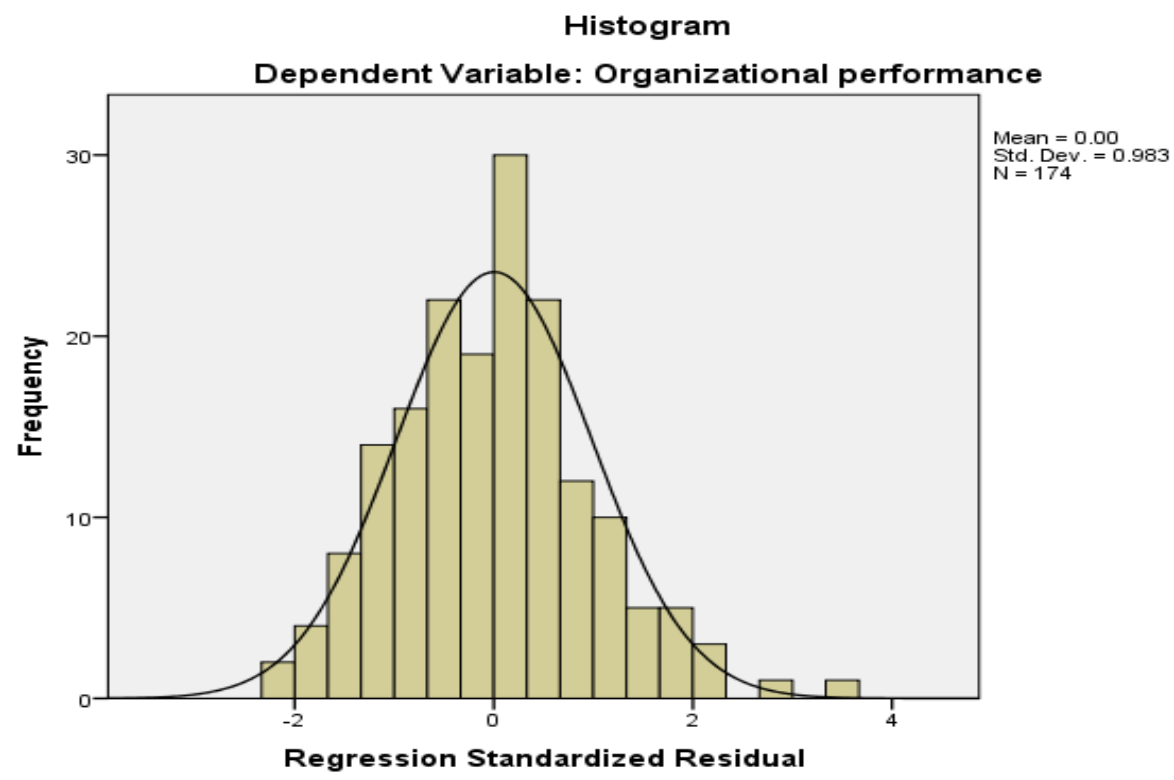

Appendix-2: Normal p-p plot of regression standardized residual

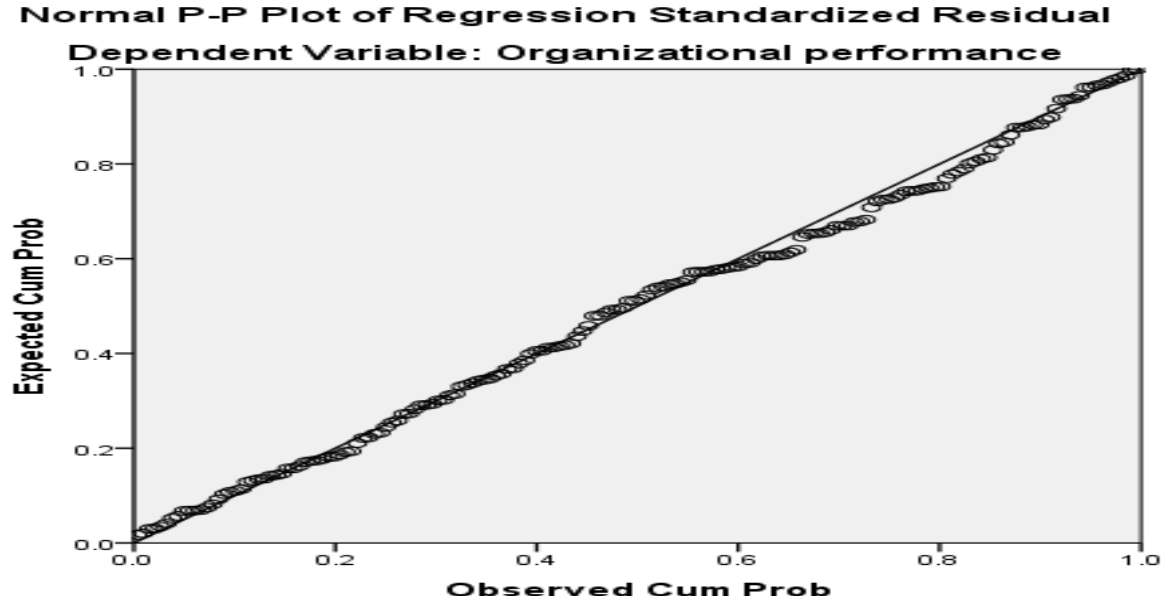

Appendix 3: Collinearity statistics

\begin{tabular}{|l|l|l|}
\hline \multirow{2}{*}{ Variable } & Collinearity Statistics \\
\cline { 2 - 3 } & Tolerance & VIF \\
\hline (Constant) & & \\
\hline TMC & .842 & 1.188 \\
\hline EI & .931 & 1.074 \\
\hline CF & .887 & 1.128 \\
\hline SQM & .883 & 1.133 \\
\hline CI & .779 & 1.283 \\
\hline EDUT & .852 & 1.173 \\
\hline
\end{tabular}


Appendix-4: Homoscedasticity test

Scatterplot

Dependent Variable: Organizational performance

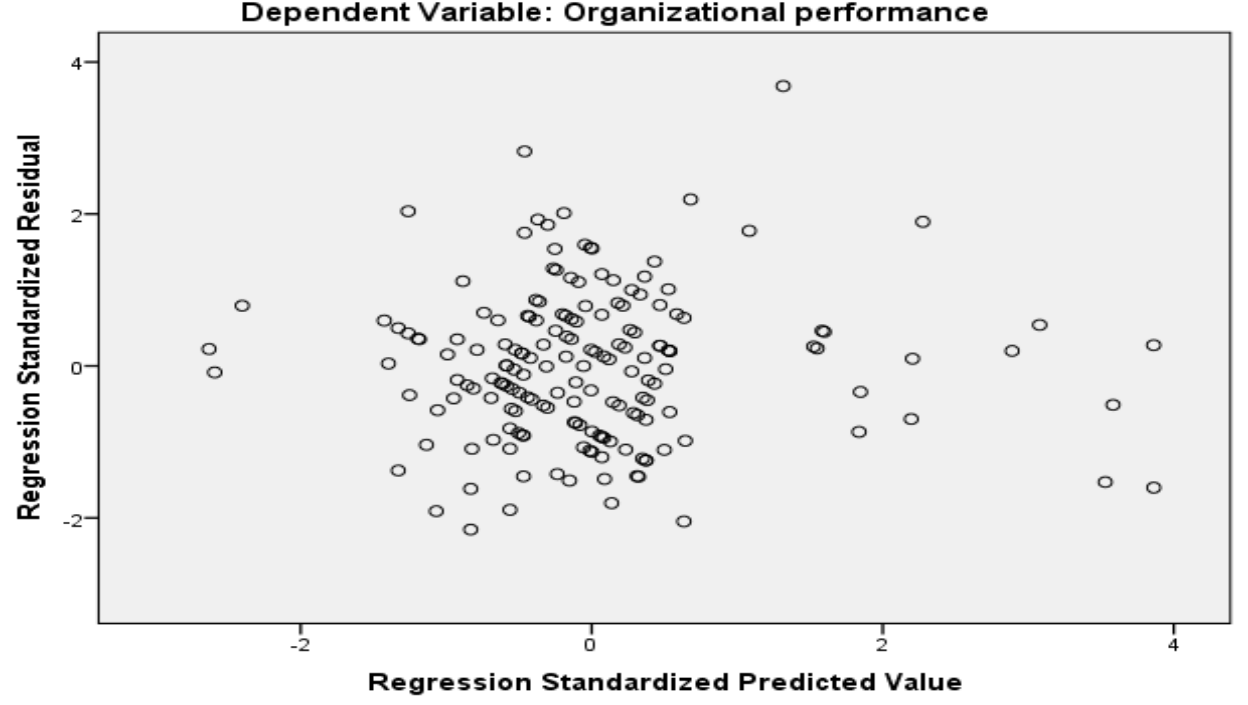

